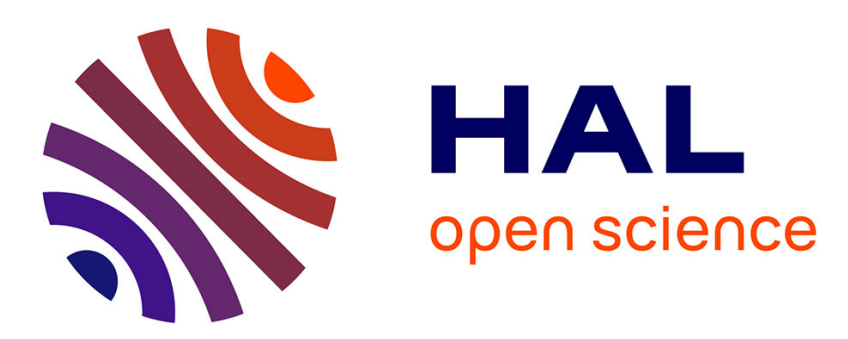

\title{
Amino-nanopolystyrene exposures of oyster (Crassostrea gigas) embryos induced no apparent intergenerational effects
}

K. Tallec, Ika Paul-Pont, Bruno Petton, Marianne Alunno-Bruscia, C. Bourdon, I. Bernardini, M. Boulais, Christophe Lambert, C. Quere, Antoine

Bideau, et al.

\section{To cite this version:}

K. Tallec, Ika Paul-Pont, Bruno Petton, Marianne Alunno-Bruscia, C. Bourdon, et al.. Aminonanopolystyrene exposures of oyster (Crassostrea gigas) embryos induced no apparent intergenerational effects. Nanotoxicology, 2021, 15 (4), pp.477-493. 10.1080/17435390.2021.1879963 . hal03246774

\section{HAL Id: hal-03246774 \\ https://hal.science/hal-03246774}

Submitted on 27 Nov 2021

HAL is a multi-disciplinary open access archive for the deposit and dissemination of scientific research documents, whether they are published or not. The documents may come from teaching and research institutions in France or abroad, or from public or private research centers.
L'archive ouverte pluridisciplinaire HAL, est destinée au dépôt et à la diffusion de documents scientifiques de niveau recherche, publiés ou non, émanant des établissements d'enseignement et de recherche français ou étrangers, des laboratoires publics ou privés. 


\section{Nanotoxicology \\ Nanotoxicology}

\section{Amino-nanopolystyrene exposures of oyster (Crassostrea gigas) embryos induced no apparent intergenerational effects}

K. Tallec , I. Paul-Pont, B. Petton, M. Alunno-Bruscia , C. Bourdon , I. Bernardini , M. Boulais , C. Lambert , C. Quéré , A. Bideau, N. Le Goïc , A.-L. Cassone , F. Le Grand , C. Fabioux, P. Soudant \& A. Huvet

To cite this article: K. Tallec , I. Paul-Pont, B. Petton , M. Alunno-Bruscia , C. Bourdon , I. Bernardini , M. Boulais, C. Lambert, C. Quéré , A. Bideau, N. Le Goïc , A.-L. Cassone , F. Le Grand , C. Fabioux , P. Soudant \& A. Huvet (2021): Amino-nanopolystyrene exposures of oyster (Crassostrea gigas) embryos induced no apparent intergenerational effects, Nanotoxicology

To link to this article: https://doi.org/10.1080/17435390.2021.1879963

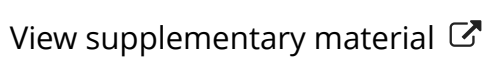

曲 Published online: 08 Feb 2021.

Submit your article to this journal $\sqsubset$

Q View related articles ¿

View Crossmark data $\leftrightharpoons$ 


\title{
Amino-nanopolystyrene exposures of oyster (Crassostrea gigas) embryos induced no apparent intergenerational effects
}

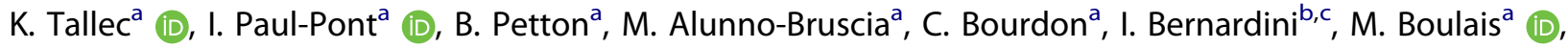 \\ C. Lambert ${ }^{a}$ (D), C. Quéréa , A. Bideau ${ }^{a}$, N. Le Goïc ${ }^{a}$, A.-L. Cassone ${ }^{a}$, F. Le Grand ${ }^{a}$, C. Fabioux ${ }^{a}$, \\ P. Soudant ${ }^{a}$ (D) and A. Huvet ${ }^{a}$

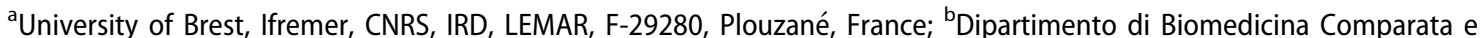 \\ Alimentazione, Università degli Studi di Padova, Padova, Italy; ${ }^{C}$ Department of Physical, Earth and Environmental Sciences, University \\ of Siena, Siena, Italy
}

\section{ABSTRACT}

Early life stages (ELS) of numerous marine invertebrates mustcope with man-made contaminants, including plastic debris, during their pelagic phase. Among the diversity of plastic particles, nano-sized debris, known as nanoplastics, can induce effects with severe outcomes in ELS of various biological models, including the Pacific oyster Crassostrea gigas. Here, we investigated the effects of a sub-lethal dose $\left(0.1 \mu \mathrm{g} \mathrm{mL}^{-1}\right)$ of $50 \mathrm{~nm}$ polystyrene nanobeads (nano-PS) with amine functions on oyster embryos ( $24 \mathrm{~h}$ exposure) and we assessed consequences on larval and adult performances over two generations of oysters. Only a few effects were observed. Lipid analyses revealed that first-generation (G1) embryos exposed to nano-PS displayed a relative increase in cardiolipin content $(+9.7 \%)$, suggesting a potential modification of mitochondrial functioning. G1-larvae issued from exposed embryos showed decreases in larval growth (-9\%) and lipid storage (-20\%). No effect was observed at the G1 adult stage in terms of growth, ecophysiological parameters (clearance and respiration rates, absorption efficiency), or reproductive outputs (gonadic development, gamete quality). Second generation (G2) larvae issued from control G1 displayed a significant growth reduction after G2 embryonic exposure to nano-PS (-24\%) compared to control (as observed at the first generation), while no intergenerational effect was detected on G2 larvae issued from G1 exposed embryos. Overall, the present experimental study suggests a low incidence of a short embryonic exposure to nano-PS on oyster phenotypes along the entire life cycle until the next larval generation.

\section{ARTICLE HISTORY}

Received 5 June 2020

Revised 18 January 2021

Accepted 19 January 2021

\section{KEYWORDS}

Oyster; nanoplastics; embryonic exposure; larval performances; offspring

\section{Introduction}

Since 1950, mankind has produced 6300 million tons (Mt) of plastic waste and a large part ( $79 \%)$ was buried in landfills or dumped in the natural environment (Geyer, Jambeck, and Law 2017). Plastics debris are pervasive and contaminate all ecosystems including the marine environment as the ultimate recipient (e.g. Cole et al. 2011). Plastics debris are found everywhere in the oceans (e.g. sea ice, sediment, deep-sea) and it is estimated that 93-236000 metric tons are presently floating on the surface of the open ocean (e.g. Paul-Pont et al. 2018; van Sebille et al. 2015). The largest proportion of oceanic plastic waste, in terms of the number of pieces, has been suggested to consist of microplastics (MP; $<5 \mathrm{~mm}$ ) (i.e. $92 \%$ of plastic items at the open ocean sea surface; Eriksen et al. 2014). These include manufactured particles (e.g. facial scrubs or exfoliants; primary MP) and particles derived from the fragmentation of larger debris in seawater (secondary MP) (Cole et al. 2011). Fragmentation processes can lead to the creation of nano-sized debris, known as nanoplastics (NP $<1 \mu \mathrm{m}$ ), as demonstrated under laboratory conditions (Gigault et al. 2016; Lambert and Wagner 2016; Dawson et al. 2018; Ekvall et al. 2019; Mateos-Cárdenas et al. 2020) and recently underlined by the detection for the first time of plastic particles $<1 \mu \mathrm{m}$ in the North Atlantic subtropical gyre (Ter Halle et al. 2017). In addition to the fragmentation processes, recent works detected primary NP in cosmetics (Hernandez, Yousefi, and Tufenkji 2017) or a waste 
of industrial processes (Stephens et al. 2013; Zhang et al. 2012), being, therefore, possible direct sources in the environment. Although environmental NP concentrations are still unknown and require new and adapted methods (Mintenig et al. 2018), it is expected that their number concentrations exceed MP concentrations (Wagner and Reemtsma 2019).

The potential impacts of micro and nanoplastics (MNP) are recognized as a major concern (e.g. Galloway, Cole, and Lewis 2017). Overall, the first insights revealed that NP can induce higher toxicity than MP due to nano-properties, their nano-size and high surface-to-volume ratio enhance their reactivity and interactions with biological membranes and, therefore the risk of damages and/or particle translocations into tissues/organs (AlSid-Cheikh et al. 2018; Jeong et al. 2016; Paul-Pont et al. 2018). Various kinds of damage have been recorded in aquatic organisms upon laboratory exposures to NP, for example, decrease in reproduction and/or growth (Jeong et al. 2016; Besseling et al. 2014), behavior modifications (Chen et al. 2017), energy balance disruptions (Trevisan et al. 2019), immune perturbations (Auguste et al. 2020), alteration of cell homeostasis by membrane injury/ modifications (Feng et al. 2019; Tallec et al. 2020). Most effects have been demonstrated at the individual level, but recent findings suggested transgenerational effects (Zhao et al. 2017; Liu et al. 2020). For instance, 2-generations exposure to nanopolystyrene beads $\left(1 \mu \mathrm{g} \mathrm{L}^{-1}\right)$ reduced growth and reproduction in the recovery generation of daphnia (Liu et al. 2020). To investigate toxic potential of nanoplastics, commercial nanopolystyrene beads are used, notably amino-nanopolystyrene beads $\left(-\mathrm{NH}_{2}\right)$ due to their properties: (i) no aggregation in experimental seawater and (ii) a positive charge promoting interactions with biological membranes (e.g. Della Torre et al. 2014; Lehner et al. 2019).

Many marine invertebrates are characterized by external fertilization followed by a free larval development in seawater (Pechenik 1999). Thus, early life stages (ELS) must cope with stressors in seawater, notably in coastal areas that are heavily affected by human activities (Halpern et al. 2008). ELS are commonly used as biological models in risk assessments notably to evaluate the toxicity of plastic debris (e.g. Beiras et al. 2018). In this regard, first reports indicated high sensitivity of ELS to NP, in particular during embryogenesis (Balbi et al. 2017; Della Torre et al. 2014; Tallec et al. 2018). Embryogenesis is a key step characterized by intense morphological, cellular, and molecular changes that make embryos highly sensitive to external disruptors (Fitzpatrick et al. 2008; Sokolova et al. 2012; Bhandari, Vom Saal, and Tillitt 2015). In most cases, embryos harbor the genetic information carried over successive generations through germline differentiation during the first cleavages of embryogenesis (Leclère et al. 2012). Therefore, modifications of embryogenesis can lead to effects over generations (Bhandari, Vom Saal, and Tillitt 2015; Major et al. 2020) but no data is available, to our knowledge, on the potential repercussions of embryonic exposure to NP on subsequent stages (e.g. larvae, adults) and next generations. The present study aims to address this question by using the Pacific oyster (Crassostrea gigas) which is a key species in coastal systems. The early life stages of $C$. gigas are commonly used as a marine biological model (e.g. Mottier et al. 2013; Sussarellu et al. 2018). As demonstrated previously using a standardized bivalve embryotoxicity assay (AFNOR XP-T-90-382), oyster embryos are sensitive to $50-\mathrm{nm}$ nanopolystyrene beads, especially those with an amine functionalization $\left(50-\mathrm{NH}_{2}\right)$ with an $\mathrm{EC}_{50}$ of $0.15 \mu \mathrm{g} \mathrm{mL}^{-1}$ (Tallec et al. 2018). Overall, oyster embryos displayed similar sensitivity to mussel embryos (50- $\mathrm{NH}_{2}$ exposure, $\mathrm{EC}_{50}: 0.14 \mu \mathrm{g} \mathrm{m}^{-1}$; Balbi et al. 2017) but higher than other ELS models such as sea urchins embryos $\left(50-\mathrm{NH}_{2}\right.$ exposure, $\mathrm{EC}_{50}: 2.61 \mu \mathrm{g} \mathrm{mL}^{-1}$; Della Torre et al. 2014), rotifer larvae $\left(50-\mathrm{NH}_{2}\right.$ exposure, $\mathrm{EC}_{50}: 2.75-6.62 \mu \mathrm{g} \mathrm{mL}{ }^{-1}$, Manfra et al. 2017) or zebrafish embryos $(20 \mathrm{~nm}$ PS beads exposure, $\mathrm{EC}_{50}$ : 21.5-52.2 $\mu \mathrm{g} \mathrm{mL}^{-1}$; Zhang and Goss 2020). With the aim of testing the consequences of sub-lethal effects induced by these particles on embryonic development, including potential effects at the adult stage and imprinting affecting the next generation, the present study assessed the effects of short term ( $24 \mathrm{~h}$ ) embryonic exposure to $50-\mathrm{NH}_{2}$ beads at a sub-lethal dose $\left(0.1 \mu \mathrm{g} \mathrm{mL}^{-1}\right.$; Tallec et al. 2018) over two generations. Effects on oyster performances were examined at both larval (growth, development, settlement) and adult stages (growth, clearance and respiration rates, reproductive outputs) at the first generation and on larval performances at the second generation. 


\section{Materials and methods}

\subsection{Nanopolystyrene beads}

Nanopolystyrene beads (nano-PS; $50 \mathrm{~nm}$ ) with an amine functionalization $\left(50-\mathrm{NH}_{2}\right)$ were purchased from Bangs Laboratories (USA). This nano-PS did not have any fluorescent labeling. Polystyrene polymer chemistry was confirmed by Raman microspectroscopy (LabRAM HR800 Raman; Horiba Scientific; Japan) (Tallec et al. 2018). Particles were characterized in $1-\mu \mathrm{m}$ filtered, UV-treated seawater (SW; $20^{\circ} \mathrm{C}, \mathrm{pH}$ 8.1, PSU 34, I $0.678 \mathrm{~mol} \mathrm{~L}^{-1}$ ) by Dynamic Light Scattering (DLS; Zetasizer NanoZS; Malvern Instruments; UK) at a concentration of $100 \mu \mathrm{g} \mathrm{mL}^{-1}$. This concentration was used for DLS analysis owing to the occurrence of artifacts at lower concentrations. DLS results showed that the $50-\mathrm{NH}_{2}$ suspension formed at $\mathrm{T}_{0}$ and $\mathrm{T}_{24 \mathrm{~h}}$ small aggregates $(97 \pm 2 \mathrm{~nm})$ in SW with a positive surface charge $(16 \pm 3 \mathrm{mV}$ ) (see details in Tallec et al. 2018). The stock suspension was kept at $4{ }^{\circ} \mathrm{C}$ and diluted in ultrapure water at $1 \mathrm{mg} \mathrm{mL}^{-1}$ just before the final dilution in SW for the exposures.

\subsection{Broodstock}

The initial broodstock (18-month-old-mature oysters C. gigas; generation $0, \mathrm{G} 0$ ) was collected from a farming area in the Bay of Brest $\left(48^{\circ} 20^{\prime} 6^{\prime \prime} \mathrm{N}\right.$, $4^{\circ} 19^{\prime} 6^{\prime \prime} \mathrm{W}$; seawater features: $18.9^{\circ} \mathrm{C}, \mathrm{pH}$ 8.0, PSU 34.6) before being transferred to Ifremer's experimental facilities (Argenton, France) in June 2018. These oysters were acclimatized in a $350 \mathrm{~L}$ tank supplied with SW $\left(16.5^{\circ} \mathrm{C}\right)$ containing a balanced mixture of two microalgae, Tisochrysis lutea (T-iso CCAP927/14, cell volume $=40 \mu \mathrm{m}^{3}$ ) and Chaetoceros sp. (CCAP 1010/3, cell volume = $80 \mu \mathrm{m}^{3}$ ).

\subsection{Experimental design}

The experimental design used to breed, expose, and rear oysters over two generations is summarized in Figure 1. The first generation of oyster embryos (G1) was produced in June 2018 from the initial broodstock G0 according to a standardized bivalve embryotoxicity assay (AFNOR XP-T-90-382) adapted to an aquaculture experimental design. Gametes from 5 males and 5 females were collected by stripping. Precautions were taken to avoid polyspermy: oocytes were incubated in SW during $45 \mathrm{~min}$ before fertilization and the spermatozoa-to-oocyte ratio was set at a much lower ratio than the one identified as leading to high risk of polyspermy in oysters (1000:1; Bayne 2017; Alliegro and Wright 1983, Luis Stephano and Gould, 1988). Gametes were pooled in $1.8 \mathrm{~L}$ of SW $\left(21^{\circ} \mathrm{C}\right)$ with a spermatozoa-to-oocyte ratio of $100: 1$ and a final concentration of 1000 oocytes $\mathrm{mL}^{-1}$. Gamete concentrations were estimated using an EasyCyte Plus cytometer (Guava Merck Millipore, USA). The fertilization yield (\%; [number of fertilized oocytes/number of oocytes] $\times 100$ ) estimated after $1.5 \mathrm{~h}$ of contact between gametes was $95 \pm 3 \%$ ( $n=12$ beaker replicates). Thereafter, G1 embryos (2-4 cells) were placed in 5-L glass beakers (100 embryos $\mathrm{mL}^{-1} ; 21^{\circ} \mathrm{C}$ ) and divided into two treatments ( $n=12$ beaker replicates per treatment; Step 1): G1 embryos without exposure corresponding to the control (G1-C) and $\mathrm{G} 1$ embryos exposed to $50-\mathrm{NH}_{2}$ beads at $0.1 \mu \mathrm{g} \mathrm{mL}^{-1}$ (G1-E). The embryonic exposure lasted $24 \mathrm{~h}$, which corresponds to the time needed to reach the final stage of oyster embryogenesis, the D-larva (Robert and Gérard 1999). Therefore, all the embryonic stages, 2-4-8 cells, morula, blastula, gastrula, and trochophore were exposed. At the end of the exposure, all beaker contents were sieved at $40 \mu \mathrm{m}$ to estimate the Dlarval yield (\%; the number of D-larvae/number of fertilized oocytes $\times 100)$ and the normal D-larval yield (\%; the number of normal D-Larvae/(number of normal D-Larvae + number of abnormal DLarvae) $\times 100$ ). Abnormal D-larvae referred to the mantle and/or shell malformations or developmental arrest during embryogenesis (Mottier et al. 2013). Lipid (see Section 2.4) and scanning electron microscopy (see Section 2.5) samplings were also performed at this step. The remaining normal D-larvae were rinsed with SW to remove the nano-PS and 100000 individuals per replicate and per treatment were transferred to the larval rearing system to complete their pelagic phase until settlement ( $\sim 16$ days post fertilization, $\mathrm{dpf}$ ) in order to evaluate mid-term consequences (larval performances) of the embryonic exposure (see Section 2.6; Step 2). All nano-PS contaminated waters were stored in sealed containers and treated as hazardous chemicals. 


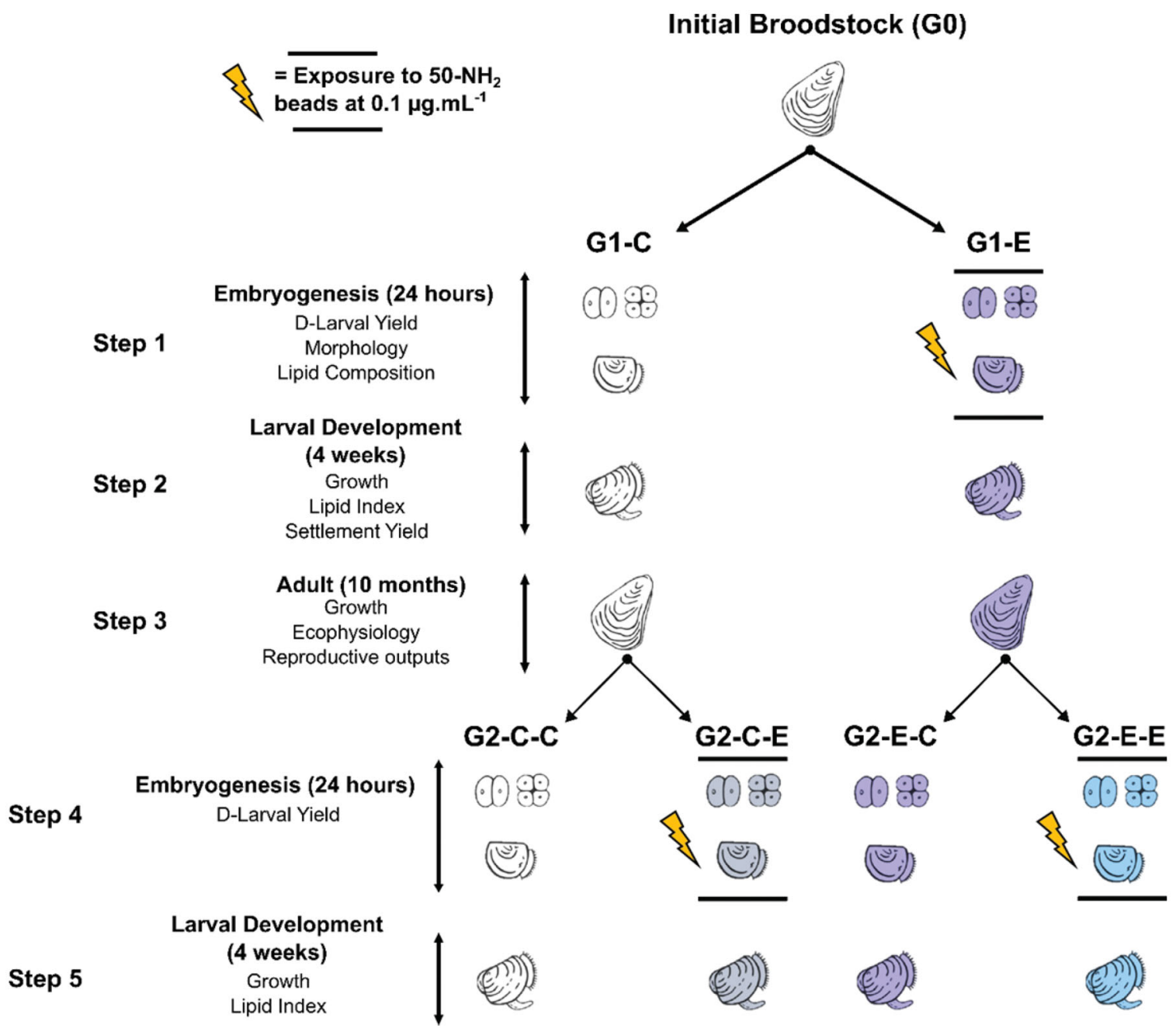

Figure 1. Experimental design of the embryonic exposures over two generations of oysters. Lightning bolts indicate the 24-h embryonic exposures to $50-\mathrm{nm}$ amino-nanopolystyrene beads $\left(50-\mathrm{NH}_{2}\right)$ at $0.1 \mu \mathrm{g} \mathrm{mL}{ }^{-1}$. Parameters analyzed at each step are listed on the left-hand side of the figure. Illustrations of the oyster life cycle were adapted from Vogeler et al. (2016).

Long-term consequences of the embryonic exposure were investigated on adult performances (G1) and larval performances of the next generation (G2). Once larvae settled, $2000 \mathrm{G} 1$ oyster seeds per treatment (G1-C and G1-E; 50-days-old) were transferred to the Ifremer nursery (Bouin, France) in August 2018, where they were reared in onshore facilities for 8 months with UV-treated, filtered seawater and Skeletonema costatum ad libitum. Oyster growth was monitored every 1-2 months over this period (see Section 2.7). In April 2019, 632 adult oysters per treatment (G1-C and G1-E; 10 months old) were returned to Ifremer's experimental facilities in Argenton to complete gametogenesis. These oysters were placed in four 350-L tanks in a common garden scheme (158 oysters per treatment per tank) in order to avoid any bias due to putative differences among the four tanks and their positions in the experimental room. G1 adult oysters were maintained for 10 weeks at $17^{\circ} \mathrm{C}$ and fed continuously on a mixed diet of $T$. lutea/Chaetoceros sp. $(50 / 50, v / v)$ at a mean concentration of $2000 \mu \mathrm{m}^{3}$ $\mu \mathrm{L}^{-1}$ to ensure complete gametogenesis (conditioning period). Oyster growth and ecophysiology (clearance and respiration rates, absorption efficiency) were monitored throughout this conditioning period (see Section 2.8; Step 3).

After 10 weeks of conditioning, once the G1 oysters were mature, the sex ratio and gamete quality were compared between treatments (G1-C and G1$E_{\text {; }}$ see Section 2.9). The second generation of embryos (G2) was produced by pooling oyster gametes within each treatment following the same protocol described above (Step 4). There were four treatments in the G2 embryonic exposure experiment $(n=4$ beaker replicates per treatment; $n$ was 
reduced as number of treatment has increased in comparison to the $\mathrm{G} 1$ experiment): (i) $\mathrm{G} 2$ embryos from $\mathrm{G} 1-\mathrm{C}$ adults with no $\mathrm{G} 2$ embryonic exposure (G2-C-C), (ii) $\mathrm{G} 2$ embryos from G1-C adults with $\mathrm{G} 2$ embryonic exposure to $50-\mathrm{NH}_{2}$ beads at $0.1 \mu \mathrm{g}$ $\mathrm{mL}^{-1}$ (G2-C-E), (iii) G2 embryos from G1-E adults without $\mathrm{G} 2$ embryonic exposure (G2-E-C), (iv) G2 embryos from G1-E adults with $\mathrm{G} 2$ embryonic exposure to $50-\mathrm{NH}_{2}$ beads at $0.1 \mu \mathrm{g} \mathrm{mL} \mathrm{m}^{-1}$ (G2-E-E). As in the G1, embryonic exposure was stopped after $24 \mathrm{~h}$, the D-larval and normal D-larval yields were estimated then 100000 normal D-larvae per replicate per treatment were rinsed and placed in the larval rearing system to complete the pelagic phase.

\subsection{Lipid composition (G1 - step 1)}

Potential lipid content (classes and fatty acids) modifications were investigated because membrane impairments are proposed as the leading cause of the nano-PS toxicity (e.g. Feng et al. 2019; González-Fernández et al. 2020). At the end of the G1 embryonic development and nano-PS exposure, 200000 normal D-larvae per replicate per treatment were collected on GF/F glass-fibre filters $(0.2 \mu \mathrm{m}$; Whatman ${ }^{\circledR}$; burnt beforehand at $450{ }^{\circ} \mathrm{C}$ for $6 \mathrm{~h}$ ). Their lipid content was extracted in $6 \mathrm{~mL}$ chloroform:methanol $(2: 1 \mathrm{v} / \mathrm{v})$ and stored at $-20^{\circ} \mathrm{C}$ (Da Costa et al. 2016). Lipid class composition was determined by high-performance thin layer chromatography (HPTLC) using glass plates coated with silica $\left(200 \times 100 \mathrm{~mm}\right.$; Merck ${ }^{\circledR} 60$, Germany) (Da Costa et al. 2016). To specifically analyze neutral lipids $(\mathrm{NL})$ and polar lipids (PL), plate preparations were conducted using different mixtures: (i) hexane:diethyl ether $(97: 3 ; \mathrm{v} / \mathrm{v})$ for $\mathrm{NL}$; (ii) methyl acetate:isopropanol:chloroform:methanol:0.25\% $\mathrm{KCl}$ (10:10:10:4:3.6; v/v) for PL. Thereafter, lipid extracts were spotted onto these plates using an automatic TLC sampler ATS4 (CAMAG $^{{ }^{\circ}}$; Switzerland). Separation of NL was performed using two successive mixtures: (1) hexane:diethyl ether:acetic acid $(20: 5: 0.5 ; \mathrm{v} / \mathrm{v}) ;(2)$ hexane:diethyl ether $(97: 3 ; \mathrm{v} / \mathrm{v})$. Separation of $\mathrm{PL}$ was made with a mixture of methyl

acetate:isopropanol:chloroform:methanol:0.25\% $\mathrm{KCl}$ (10:10:10:4:3.6; v/v). Plates were revealed using a $3 \% \mathrm{CuSO}_{4}$ and $8 \% \mathrm{H}_{3} \mathrm{PO}_{4}(\mathrm{w} / \mathrm{v}$ in distilled water) solution, then analyzed with a scanner densitometer at $370 \mathrm{~nm}$ (TLC Scanner 4 CAMAG $^{\circ}$; Switzerland). Results were analyzed using VisionCATS software (v2.5; CAMAG $^{\mathrm{C}}$; Switzerland) (Moutel et al. 2016). Lipid classes were expressed as the mass percentage of each class in the total lipid content of a Dlarva (ng D-larva ${ }^{-1}$ ). Analyses of $\mathrm{NL}$ and $\mathrm{PL}$ allowed identification of: (i) three classes of storage lipids: triglycerides (TG), sterol esters (StE) and glyceryl ethers (GE); (ii) one class used as a proxy of lipid degradation: free fatty acids (FFA); (iii) seven classes of membrane lipids: phosphatidylethanolamine (PE), phosphatidylinositol (PI) + ceramide amino-ethylphosphonate (CAEP), phosphatidylserine (PSer), cardiolipin (CL), phosphatidylcholine (PC) and sterols (ST).

To examine fatty acid (FA) composition, $1 \mathrm{~mL}$ of lipid extract was evaporated under $\mathrm{N}_{2(\mathrm{~g})}$, recovered by three chloroform:methanol $(98: 2, \mathrm{v} / \mathrm{v})$ washings $(0.5 \mathrm{~mL})$, then deposited at the top of a silica microcolumn $(40 \times 5 \mathrm{~mm})$ to separate the polar and neutral fractions as described in Le Grand et al. (2014). Samples were successively evaporated under $\mathrm{N}_{2(\mathrm{~g})}$ and transesterified in $800 \mu \mathrm{L} \mathrm{MeOH}-\mathrm{H}_{2} \mathrm{SO}_{4}(3.4 \% \mathrm{v} /$ v) for $10 \mathrm{~min}$ at $100^{\circ} \mathrm{C}$ to obtain fatty acid methyl esters (FAME). FAME were analyzed using a Varian CP8400 gas chromatograph (HP, USA) according to Le Grand et al. (2014). FAs were expressed as the mass percentage of each FA in the total FA content per fraction (neutral or polar).

\subsection{Scanning electron microscopy (G1 - step 1)}

Aliquots of G1-C and G1-E D-larvae were fixed for $1 \mathrm{~h}$ in a mixture of $6 \%$ glutaraldehyde: $7 \% \mathrm{NaCl}: 0.4$ $M$ cacodylate $(2: 1: 1 ; \mathrm{v} / \mathrm{v})$ before being rinsed in a mixture of $0.4 \mathrm{M}$ cacodylate: $8 \% \mathrm{NaCl}$ :ultrapure water (1:1:2; v/v; 3 baths, $15 \mathrm{~min})$. Thereafter, samples were dehydrated in the following successive solutions: (1) $50 \%$ ethanol (2 baths, $10 \mathrm{~min}$ ); (2) $70 \%$ ethanol ( 2 baths, $10 \mathrm{~min}$ ); (3) $90 \%$ ethanol ( 2 baths, $10 \mathrm{~min}$ ); (4) absolute ethanol (3 baths, $15 \mathrm{~min}$ ); (5) absolute ethanol:hexamethyldisilazan (HMDS) (3:1, $\mathrm{v} / \mathrm{v} ; 15 \mathrm{~min}) ;(6)$ absolute ethanol:HMDS (1:1, v/v; $15 \mathrm{~min}) ; \quad(7)$ absolute ethanol:HMDS (1:3, v/v; $15 \mathrm{~min}$ ); (8) pure HMDS (2 baths, $15 \mathrm{~min}$ ) according to Foulon et al. (2016). Lastly, samples were coated with gold-palladium and scanning electron microscopy (SEM) observations (Hitachi S-3200N, Japan) 
were performed on a dozen of larvae per treatment. G2 D-larvae could unfortunately not be analyzed due to a failed fixation of larvae.

\subsection{Larval rearing and settlement (G1 - step 2 and $\mathrm{G} 2$ - step 5)}

G1 and G2 larvae were reared in 5-L cylinders at a density of 20 larvae $\mathrm{mL}^{-1}$ using a flow-through rearing system at $25^{\circ} \mathrm{C}$ (Rico-Villa et al. 2008). Cylinder replicates ( 12 per treatment for $\mathrm{G} 1$ and 4 per treatment for $\mathrm{G} 2$ ) were randomly positioned in the system. Larvae were continuously supplied with SW containing a mixed diet of $T$. lutea/C. neogracile $(50 / 50, v / v)$ at a mean concentration of $1500 \mu \mathrm{m}^{3}$ $\mu L^{-1}$. For $G 1$ and $G 2$, aliquots of 20-30 larvae were sampled every 2-3 days from each cylinder and fixed in a formaldehyde-seawater solution $(0.1 \%$ final) to evaluate the larval growth by image analysis using ImageJ software. For G1, when more than $50 \%$ of larvae reached the metamorphosiscompetent stage (i.e. eyed-larvae stage) in each replicate per treatment, the treatment was sieved on $80-\mu \mathrm{m}$ mesh and 20000 larvae were transferred to 30-L tanks at $25^{\circ} \mathrm{C}$ to settle on cultch using a downwelling system ( $n=4-6$ batches per treatment for G1 and $n=2$ for G2) as described in Petton et al. (2013). For G2, another method was used, all treatments were settled at the same time when more than $50 \%$ of larvae in one treatment had reached the metamorphosis-competent stage. As settlement measurements were not performed following the same protocol, results for this endpoint were therefore not comparable between generations. For G1 and G2 an aliquot of competent eyedlarvae ( $n=10$ larvae per replicate) was sampled and stained with an SW-Nile Red $\left(0.00125 \mathrm{mg} \mathrm{mL}^{-1}\right)$ solution for $1.5 \mathrm{~h}$ before fixation in a formaldehydeseawater solution $(0.1 \%$ final) to evaluate the lipid index (arbitrary units, A.U.), i.e. the relative amount of storage lipids, using a Zeiss AxioObserver Z1 (Germany). The lipid index for one larva was defined as: fluorescent area/total area (Talmage and Gobler 2010). Image analysis was again performed using ImageJ software. In the settlement system, larvae were fed continuously on the same diet used for larval rearing. After 14 days in the downwelling system, all tanks were sieved on $400-\mu \mathrm{m}$ mesh to evaluate the settlement yield (\%) defined as: (number of settled larvae/number of total larvae) $x$ 100. The G1 settled larvae were again put in the downwelling system before being transferred to the Ifremer nursery (Bouin, France) for the growth period (August 2018 to March 2019).

\subsection{Adult growth monitoring (G1 - step 3)}

G1 adult growth was monitored at the Ifremer nursery by sampling 30 oysters per treatment in November 2018, January, February, and March 2019. The collected oysters were stored at $-20^{\circ} \mathrm{C}$ until measurements of the dry flesh mass used as a proxy of oyster growth (Savina and Pouvreau 2004). Similarly, 20 oysters per treatment per tank were sampled for growth measurements at 3, 5, 7, and 10 weeks after the beginning of the conditioning period in Argenton (April-June 2019).

\subsection{Ecophysiological measurements (G1 - step 3)}

An ecophysiological measurement system was used to determine the individual clearance $\left(C R ; \mathrm{L} \mathrm{h}^{-1}\right.$ ind $^{-1}$ ) and respiration ( $\mathrm{RR} ; \mathrm{mg} \mathrm{O}_{2} \mathrm{~h}^{-1}$ ind $^{-1}$ ) rates of $\mathrm{G} 1$ adult oysters ( $\mathrm{G} 1-\mathrm{C}$ and $\mathrm{G} 1-\mathrm{E}$ ). This system consists of nine individual flow-through chambers $(0.54 \mathrm{~L})$ supplied with seawater pumped into the conditioning tank at a constant flow rate of $30 \mathrm{~mL}$ $\min ^{-1}$. These chambers are managed by a programmable controller that enables high-frequency automatic recordings of fluorescence (food supply), oxygen concentrations, and water flow in the seawater outflow (Pousse et al. 2018). We used a WTW multiparameter meter (WTW Multi 3430), a WETStar fluorimeter (WSCHL-1400 WETLABS; USA) and a SONOFLOW CO.55 ultrasonic flow rate meter (Sonotec; Germany). For each set of measurements (also referred to here as trials), all the biological and physico-chemical parameters mentioned above were recorded every $3.5 \mathrm{~h}$ over 4 days on four oysters per treatment, with each of the oysters in a separate individual chamber. This procedure was replicated four times, thus collecting individual data from 16 oysters per treatment by the end of the adult experiment. For each trial, one chamber was left empty, thus providing a control chamber (CC). The individual clearance rate (CR) of each oyster is estimated as: $\mathrm{CR}=\left(\mathrm{fl} \times\left(C_{\mathrm{CC}}-C_{\mathrm{N}}\right) / C_{\mathrm{CC}}\right)$, where $\mathrm{fl}$ is the flow rate through the chamber $\left(\mathrm{L} \mathrm{h}^{-1}\right), C_{\mathrm{CC}}$ is 
the concentration of microalgae in the control chamber and $C_{N}$ is the concentration of microalgae in a chamber with one oyster (Bayne 2017). The individual respiration rate is defined as: $R R=f l \times$ $\left(O_{\mathrm{CC}}-O_{\mathrm{N}}\right)$, where $\mathrm{fl}$ is the flow rate through the chamber $\left(\mathrm{L} \mathrm{h}^{-1}\right), O_{\mathrm{CC}}$ and $O_{\mathrm{N}}$ are the concentrations of $\mathrm{O}_{2}\left(\mathrm{mg} \mathrm{O}_{2} \mathrm{~L}^{-1}\right)$ in the control chamber and in a chamber with one oyster, respectively (Savina and Pouvreau 2004). At the end of each trial, all oysters were sacrificed and stored at $-20^{\circ} \mathrm{C}$ before measuring the dry flesh mass in order to calculate mass standardized clearance and respiration rates for an equivalent individual of $1 \mathrm{~g}$ dry tissue ( $\mathrm{dw}$ std) (Bayne, Hawkins, and Navarro 1987). In addition, absorption efficiency ( $A E, \%)$ of organic matter from ingested microalgae was calculated according to Conover's method by collecting feces twice a week from each chamber: $\mathrm{AE}=(f-e) /((1-e) \times f)$, where $f$ corresponds to the organic fraction of the diet and $e$ is the organic fraction of the feces (Conover 1966).

\subsection{Reproductive measurements (G1 - step 3)}

The gonadic development and sex ratio were assessed by histology on 20 oysters per treatment every 2 weeks during the conditioning period. A $3 \mathrm{~mm}$ cross-section of the visceral mass was cut and fixed in modified Davidson's solution at $4{ }^{\circ} \mathrm{C}$ for $48 \mathrm{~h}$. Thereafter, samples were dehydrated in ascending ethanol solutions, embedded in wax paraffin, and stained with Harris' hematoxylin-eosin as described in Fabioux et al. (2005). Sections were observed under a microscope (Leica DMIRB; Germany) and gametogenic stages were determined according to Steele and Mulcahy (1999).

Once the G1 oysters were reproductively mature, four pools of spermatozoa and oocytes, each issued from 5 males and 5 females, respectively (total number $=40$ oysters per treatment), were used to examine gamete quality and fertilization efficiency. Spermatozoa behavior (percentage of motile spermatozoa and Velocity of the Average Path (VAP; $\mu \mathrm{m}$ $\left.\mathrm{s}^{-1}\right)$ ) were analyzed using a CASA (computerassisted sperm analyser) plug-in for ImageJ according to Boulais et al. (2015); a minimum of 100 spermatozoa per replicate were analyzed. Briefly, $100 \mu \mathrm{L}$ of the spermatozoa solution $\left(1 \times 10^{8}\right.$ spermatozoa $\mathrm{mL}^{-1}$ ) of each replicate were diluted in
$300 \mu \mathrm{L}$ of SW containing pluronic acid $\left(1 \mathrm{~g} \mathrm{~L}^{-1}\right)$, then placed in FastRead cells (Fischer Scientific ${ }^{\circledR}$, USA) to acquire videos (Camera Qicam Fast 1394, 60 frames $s^{-1}, 6 s$ treatment ${ }^{-1}$ ) under a microscope (Olympus BX51, Japan; $\times 20$ magnification, dark field) (Boulais et al. 2015). For oocytes, aliquots were fixed in a formaldehyde-seawater solution ( $0.1 \%$ final) and oocyte pictures were taken under a microscope (Olympus BX51, Japan; $\times 10$ magnification). Oocyte diameter $(\mu \mathrm{m})$ was assessed using ImageJ (30 oocytes were measured per replicate) as in Sussarellu et al. (2016). Gametes from the same treatment were mixed using the method described in Section 2.3 (spermatozoa-to-oocyte ratio of 100:1 and 1000 oocytes $\mathrm{mL}^{-1}$; final volume: $1.8 \mathrm{~L} ; n=4$ beaker replicates per treatment) to estimate the fertilization yield (used as a proxy of the reproductive capacity) after $1.5 \mathrm{~h}$ of contact.

\subsection{Statistical analyses}

All statistical analyses and graphical representations were done using $\mathrm{R}$ software (R Core Team 2016). Normality and variance homogeneity were verified using Shapiro-Wilk and Levene's methods, respectively. To compare fertilization yield (G2: $4 \times 10$ oysters [5 males +5 females] per treatment), D-larval yield (G1: 12 batches of 500000 embryos; G2: 4 batches of 500000 embryos), lipid index (G1: $12 \times 10$ larvae per treatment; G2: $4 \times 10$ larvae per treatment), survival (G1: 12 batches of 100000 larvae per treatment; G2: 4 batches of 100000 larvae per treatment), settlement yield (G1: 4-6 batches of 20000 per treatment), absorption efficiency (G1: 16 oysters per treatment), and gamete quality (G1: $4 \times 10$ oysters [ 5 males +5 females] per treatment), the Student's tests or one-way ANOVA were performed according to the number of treatments. Percentages were analyzed after angular transformations. Repeated measures ANOVA were conducted on growth (adults and larvae) and ecophysiological measurements (G1: 16 oysters per treatment) with pairwise comparisons using Tukey's method when necessary. Comparisons among lipid class proportions (G1: 12 batches of 100000 larvae per treatment) were made using the Student's method while comparisons between fatty acid compositions (G1: 12 batches of 100000 larvae per treatment) were screened using one-way analyses 

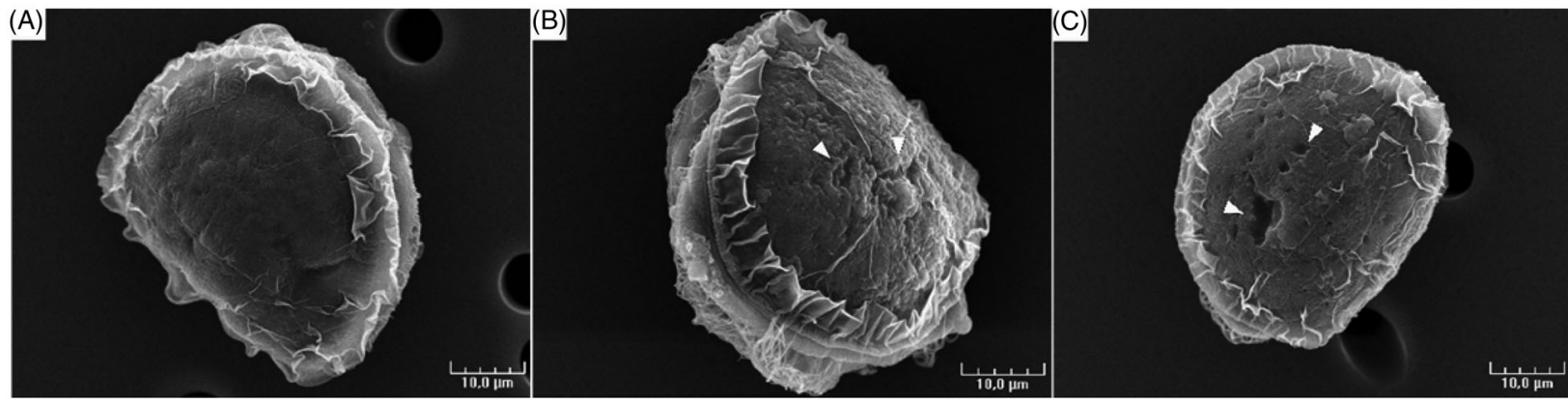

Figure 2. Scanning electron microscopy panel of G1 D-larvae (24 hpf) issued from (A) control embryos (G1-C) or (B and C) embryos exposed to 50-nm amino-polystyrene beads at $0.1 \mu \mathrm{g} \mathrm{mL} \mathrm{m}^{-1}$ (G1-E). White arrows indicate asperities and holes on the surfaces of the D-larvae. Size in $\mu \mathrm{m}$ is indicated by the scale bar.

of similarities (ANOSIM) and a Bray-Curtis similarity matrix to separate clusters $(R=1$ : perfect separation; $R=0.5$ : satisfactory separation, $R=0$ : low separation cluster). Fisher tests were used to compare sex ratio and gonadic development between treatments (20 oysters per treatment). Data were expressed as the mean \pm standard error (SE) and differences were considered significant when $p$-values $<0.05$.

\section{Results}

\subsection{Effects of embryonic exposure to nano-PS on the first oyster generation (G1)}

\subsubsection{D-Larval yield (step 1)}

At the end of embryonic development ( $24 \mathrm{~h}$ postfertilization, hpf), D-larval yields were similar in the control $(\mathrm{G} 1-\mathrm{C} ; 73.9 \pm 1.8 \%)$ and exposed treatments (G1-E; $74.3 \pm 2.3 \%)$. No differences in the abnormality level were detected between treatments under optical microscopy (average normal D-larval yield $=87.7 \pm 0.6 \%$ ). Scanning electron microscopy (SEM) observations revealed holes and/or surface asperities on 9 of the 12 observed G1-E D-larvae (75\%) while these were only observed in 3 of the 12 observed G1-C D-larvae (3) (Figure 2).

\subsubsection{Lipid composition of D-larvae (step 1)}

3.1.2.1. Lipid classes. D-larvae from the different treatments had a similar total mass of lipids $\left(9.2 \pm 0.1\right.$ and $9.5 \pm 0.3 \mathrm{ng}$ D-larva $^{-1}$ for G1-C and G1-E, respectively; $p$-value $>0.05$ ) and no significant
Table 1. Lipid class composition of G1 D-larvae (24 hpf) originating from control embryos (G1-C) and embryos exposed to 50-nm amino-polystyrene beads at $0.1 \mu \mathrm{g} \mathrm{mL}^{-1}$ (G1-E). Lipid classes are expressed as the mass percentage of each class relative to the total lipid content $(n=12$; mean \pm SE). Comparisons were made using Student's method; ${ }^{* *} p<0.01$.

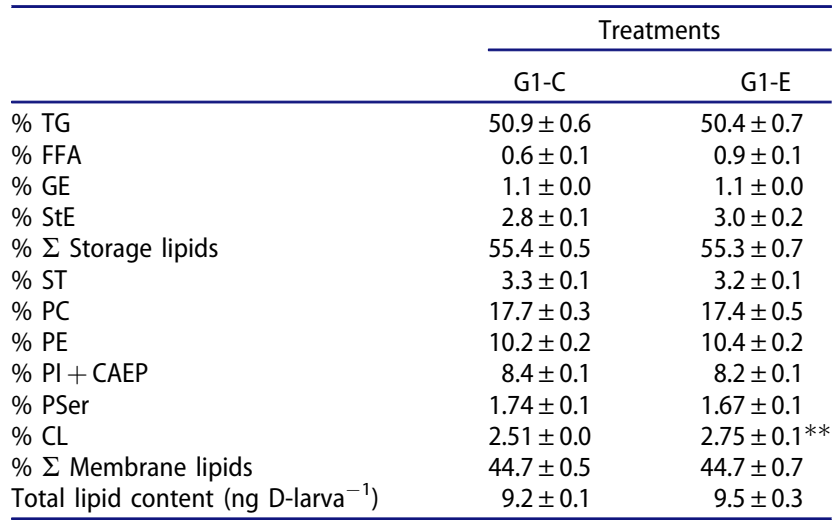

TG: triglycerides; StE: sterol esters; GE: glyceryl ethers; FFA: free fatty acids; PE: phosphatidylethanolamine, PI: phosphatidylinositol, PSer: phosphatidylserine, CL: cardiolipin; CAEP: ceramide amino-ethylphosphonate, PC: phosphatidylcholine; ST: sterols.

differences were observed in the percentages of storage and membrane lipids between the G1-E Dlarvae $(55.3 \pm 0.7 \%$ and $44.7 \pm 0.7 \%$, respectively $)$ and the G1-C D-larvae $(55.4 \pm 0.5 \%$ and $44.7 \pm 0.5 \%$, respectively). In terms of lipid class composition, only the relative percentage of cardiolipin $(\mathrm{CL})$ was statistically different between treatments, being 9.7\% higher ( $p$-value $<0.01$ ) in G1-E D-larvae compared with G1-C D-larvae (Table 1).

3.1.2.2. Fatty acid (FA) composition. The FA composition of the G1-E D-larvae was similar to that of the G1-C D-larvae according to the one-way ANOSIM $(R=0.109$ and $R=-0.031$ for polar and neutral fractions, respectively; $p$-values $>0.05$; Supplementary Tables 1 and 2). 
Table 2. Distribution of sex and gametogenic stages of G1-C (issued from control embryos) and G1-E (issued from embryos exposed to $50-\mathrm{nm}$ amino-polystyrene beads at $0.1 \mu \mathrm{g} \mathrm{mL} \mathrm{m}^{-1}$ ) oysters after 10 weeks of conditioning. Results are expressed as percentages ( $n=20$ oysters per treatment).

\begin{tabular}{llllllllll}
\hline & & \multicolumn{3}{c}{ Sex (\%) } & & \multicolumn{3}{c}{ Gametogenic stage (\%) } \\
\cline { 3 - 5 } \cline { 7 - 9 } Treatment & $n$ & Female & Male & Hermaphrodite & & 1 & 2 & 3 \\
\hline G1-C & 20 & 55 & 40 & 5 & & 0 & 15 & 85 \\
G1-E & 20 & 50 & 50 & 0 & & 0 & 5 & 95 \\
\hline
\end{tabular}

According to Steele and Mulcahy (1999), gametogenic stages correspond to: (1) developing early active; (2) developing late active; (3) mature.

3.1.3. Larval performances: growth, lipid index, and settlement yield (step 2)

G1 larvae from the G1-E treatment had a significantly lower growth rate (GR) than control larvae (G1-C; $p$-value $<0.05$; Figure 3(A)). The GR was $8.7 \%$ lower in G1-E larvae $\left(17.8 \pm 0.5 \mu \mathrm{m}\right.$ day $\left.^{-1}\right)$ compared with G1-C larvae $\left(19.5 \pm 0.4 \mu \mathrm{m} \quad\right.$ day $\left.^{-1}\right)$. Consequently, the G1-E larvae displayed a delay of one day to reach the competent larval stage, as shown by the percentages of eyed-larvae (ready to settle) at $16 \mathrm{dpf}$ : $55.5 \pm 3.3 \%$ for G1-C and $24.8 \pm 2.6 \%$ for G1-E larvae. The survival was similar ( $p$-value $>0.05$ ) between treatments (Supplementary Table 3). The lipid index (A.U.) differed significantly between treatments with a mean reduction of $19.6 \%$ in G1-E larvae compared with G1-C larvae ( $p$-value $<0.01$; Figure $3(B)$ ). The settlement yield (\%) was statistically similar between G1$\mathrm{C}$ and G1-E treatments ( $p$-value $>0.05$; Figure $3(\mathrm{C})$ ).

\subsubsection{Adult growth and ecophysiological perform- ances (step 3)}

3.1.4.1. Growth. The monitoring of $\mathrm{G} 1$ juvenile and adult growth revealed no statistical differences whether they originated from control or exposed embryos ( $p$-value $>0.05$; Figure 4). Data collected in the nursery (November 2018 - March 2019) showed that the dry mass of tissues increased 3-fold in both G1-C ( $\mathrm{T}_{\text {November: }} \quad 0.06 \pm 0.01 \mathrm{~g}$ oyster ${ }^{-1} ; \mathrm{T}_{\text {March: }}$ : $0.16 \pm 0.01 \mathrm{~g} \mathrm{oyster}^{-1}$ ) and G1-E oysters ( $T_{\text {November: }}$ : $0.05 \pm 0.01 \mathrm{~g}^{\text {oyster }}{ }^{-1} ; \mathrm{T}_{\text {March }}: 0.17 \pm 0.01 \mathrm{~g} \mathrm{oyster}^{-1}$ ). Similarly, during the conditioning period, the dry mass of tissues was $0.15 \pm 0.01 \mathrm{~g}^{\text {oyster }^{-1}}$ for G1-C and G1-E oysters at $T_{0}$ (April 2019) and increased up to $0.48 \pm 0.03$ and $0.53 \pm 0.04 \mathrm{~g}^{\text {oyster }}{ }^{-1}$ for G1-C and G1-E oysters, respectively, by $\mathrm{T}_{\mathrm{f}}$ (June 2019), corresponding to a 3-fold increase in both treatments.
3.1.4.2. Ecophysiological parameters. No significant differences ( $p$-values $>0.05$ ) were observed in individual clearance rate (CR; $\mathrm{L} \mathrm{h}^{-1} \mathrm{~g}^{-1} \mathrm{dw}$ std), respiration rate (RR; $\mathrm{mg} \mathrm{O}_{2} \mathrm{~h}^{-1} \mathrm{~g}^{-1} \mathrm{dw}$ std) or absorption efficiency $(A E ; \%)$ between adult oysters of both treatments throughout the experiment (Figure 5; Supplementary Figure 1).

\subsubsection{Reproductive outputs (step 3)}

Overall, adult oysters issued from the two treatments showed similar sex ratios and distributions of gonadic stages ( $p$-values $>0.05$ ), resulting in $85 \%$ and $95 \%$ of mature oysters after 10 weeks of conditioning for G1-C and G1-E treatments, respectively (Table 2; Supplementary Figure 2).

Regarding gamete quality, percentages of motile spermatozoa (\%) were similar ( $p$-values >0.05) between G1-C $(41.8 \pm 1.6 \%)$ and G1-E oysters $(43.6 \pm 3.0 \%)$ as were the mean velocities (VAP; $\mu \mathrm{m}$ $\left.\mathrm{s}^{-1}\right)$, estimated at $72.1 \pm 1.1 \mu \mathrm{m} \quad \mathrm{s}^{-1} \quad$ and $79.8 \pm 4.4 \mu \mathrm{m} \mathrm{s} \mathrm{s}^{-1}$, respectively. Similarly, oocyte diameters $(\mu \mathrm{m})$ were identical ( $p$-value $>0.05)$ between G1-C $(30.5 \pm 0.2 \mu \mathrm{m})$ and G1-E oysters $(30.7 \pm 0.4 \mu \mathrm{m})$. Lastly, the reproductive success was not affected by treatment, as demonstrated by high and similar fertilization yields (\%) of $90.5 \pm 1.2 \%$ for G1-C oysters and $87.3 \pm 2.3 \%$ for G1-E oysters.

\subsection{Effects of embryonic exposure to nano-PS on the second oyster generation (G2)}

\subsubsection{D-larval yield (step 4)}

No significant differences were observed in D-larval yields among the four treatments ( $p$-value $>0.05$ ) with mean values of $67.1 \pm 4.8 \%, 60.4 \pm 3.5 \%$, $64.4 \pm 5.1 \%$ and $59.5 \pm 8.1 \%$ for G2-C-C, G2-E-C, G2C-E and G2-E-E, respectively. No differences in the abnormality level were detected among treatments under optical microscopy (average normal D-larval yield $=80.5 \pm 2.8 \%$ ).

3.2.2. Larval performances: growth, lipid index, and settlement yield (step 5)

The G2 larval growth fell into two statistical groups ( $p$-value < 0.05; Figure 6(A)). G2-C-C and G2-E-C larvae had similar growth rates ( $p$-value $>0.05)$ with mean values of $17.1 \pm 0.7 \mu \mathrm{m} \quad$ day $^{-1}$ and $16.9 \pm 0.3 \mu \mathrm{m}$ day $^{-1}$, respectively. G2-C-E larvae $\left(12.9 \pm 1.8 \mu \mathrm{m} \mathrm{day}{ }^{-1}\right)$ had significantly slower 

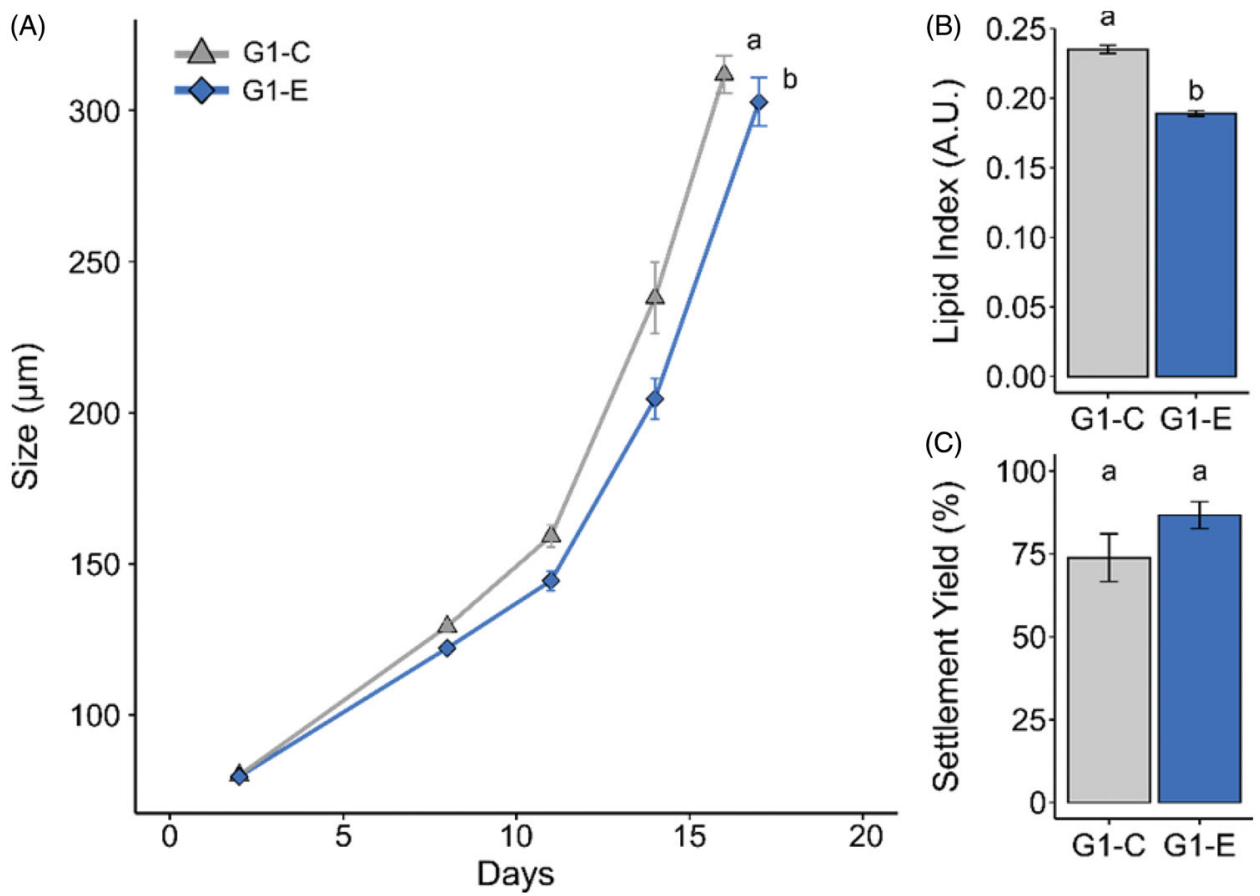

Figure 3. Size ( $\mu \mathrm{m} ; \mathrm{A})$, lipid index (A.U.; B) and settlement yield (\%; C) of G1 larvae issued from control embryos (G1-C; grey) and from embryos exposed to $50 \mathrm{~nm}$ amino-polystyrene beads at $0.1 \mu \mathrm{g} \mathrm{mL} \mathrm{m}^{-1}$ (G1-E; blue). Results are expressed as means $\pm \mathrm{SE}$ $(n=12)$. Repeated measures ANOVA were conducted to compare treatments for the size while Student's method was used for the lipid index and the settlement yield at the $5 \%$ level; homogeneous groups are indicated by the same letter.

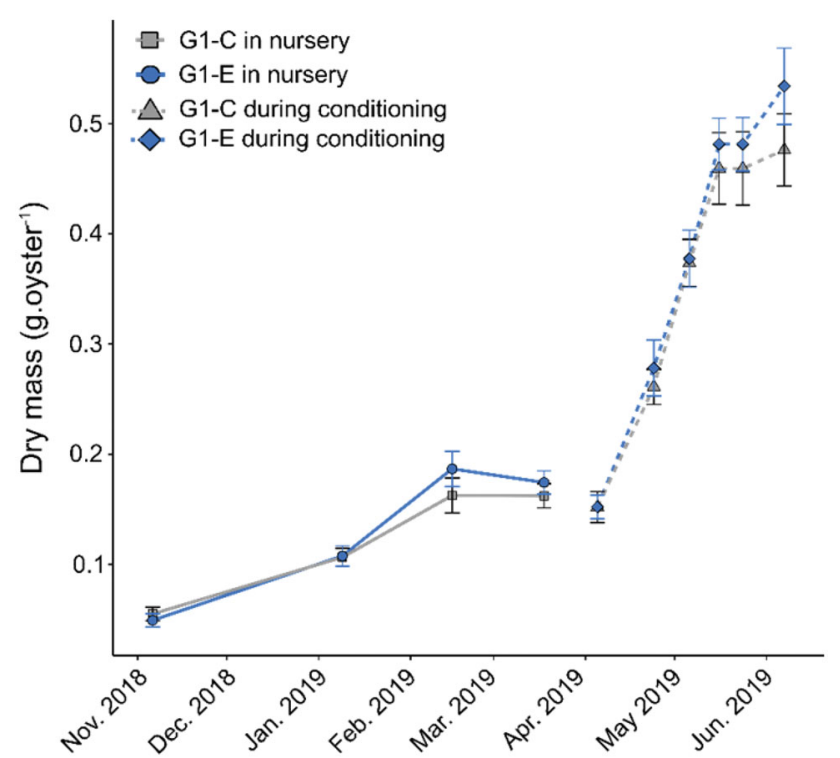

Figure 4. Dry mass (g oyster ${ }^{-1}$ ) of G1-C (grey; issued from control embryos) and G1-E oysters (blue; issued from embryos exposed to $50-\mathrm{nm}$ amino-polystyrene beads at $0.1 \mu \mathrm{g} \mathrm{mL} \mathrm{m}^{-1}$ ) during the nursery phase (solid lines; November 2018 to March 2019) and the G1 conditioning period (dashed lines; April 2019 to June 2019). Results are expressed as mean \pm SE ( $n=30$ oysters per sampling date in the nursery monitoring (in common tank) and four replicates (corresponding to four tanks) of 20 oysters per sampling date during the adult experiment). Repeated measures ANOVA were conducted to compare treatments at the $5 \%$ level. growth (-24\%) than G2-C-C and G2-E-C larvae ( $p$ value $<0.05)$, while G2-E-E larvae had an intermediate growth non-significantly different from any of the other groups (G2-C-C, G2-E-C and G2-C-E) with a mean growth rate of $14.5 \pm 2.5 \mu \mathrm{m}$ day $^{-1}$. At the end of the larval rearing (17 dpf), a delay to reach the competent larval stage was suggested with a lower percentage of eyed-larvae in the G2-C-E treatment $(20.0 \pm 8.2 \%)$ compared with G2-C-C $(49.0 \pm 4.5 \%)$, G2-E-C (43.7 $\pm 12.0 \%)$ and G2-E-E (32.8 $\pm 10.9 \%)$ larvae. Survival was similar ( $p$-value $>0.05$ ) among treatments (Supplementary Table 3). Conversely to G1 larvae, no significant differences ( $p$-value $>0.05$ ) in lipid index (A.U.) were observed among G2 larvae treatments (Figure 6(B)). The settlement yield appeared similar (no statistical test was made as there were only two replicates per treatment) among G2 larvae treatments (Figure $6(C)$ ).

\section{Discussion}

\subsection{Direct effects of nano-PS exposure during oyster embryonic development}

Embryogenesis is a sensitive step in the life cycle of marine invertebrates. This sensitivity is linked to the 
(A)

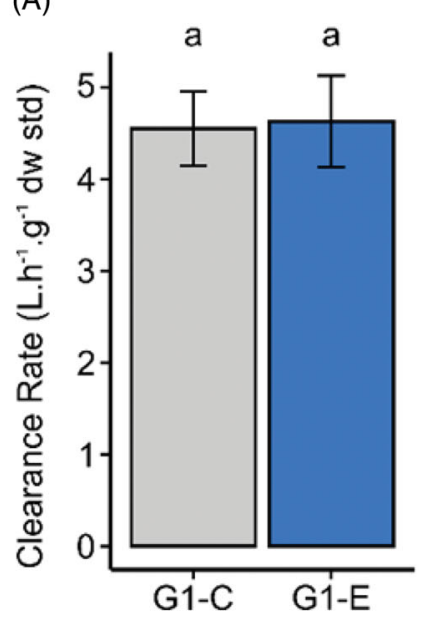

(B)

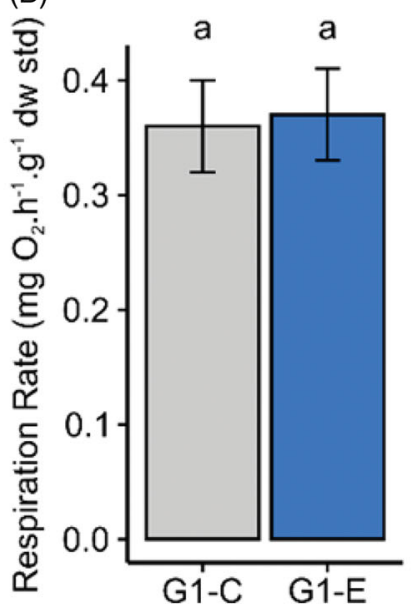

(C)

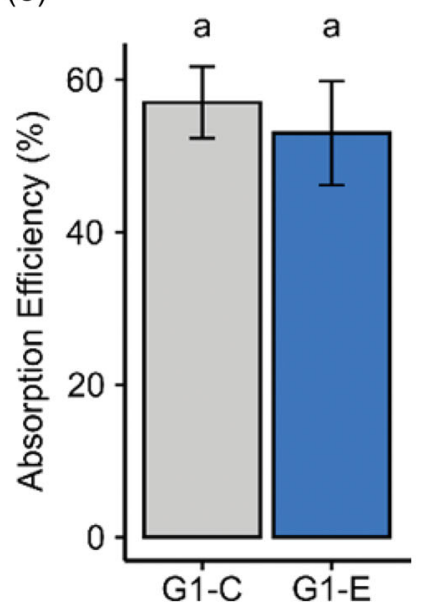

Figure 5. Individual clearance rate $\left(A ; L^{-1} g^{-1} d w s t d\right)$, respiration rate $\left(B ; m g \mathrm{O}_{2} h^{-1} g^{-1} d w s t d\right)$ and absorption efficiency (\%) in adult oysters of G1-C (grey; issued from control embryos) and G1-E (blue; issued from embryos exposed to 50-nm aminopolystyrene beads at $0.1 \mu \mathrm{g} \mathrm{mL}^{-1}$ ) treatments. Results are expressed as mean $\pm \mathrm{SE}$ ( $n=16$ oysters per treatment). Detailed data of the clearance and respiration rates are given in the Supplementary Figure 1. Repeated measures ANOVA were conducted to compare treatments for the clearance and respiration rates while Student's method was used for the absorption efficiency at the 5\% level; homogeneous groups are indicated by the same letter.
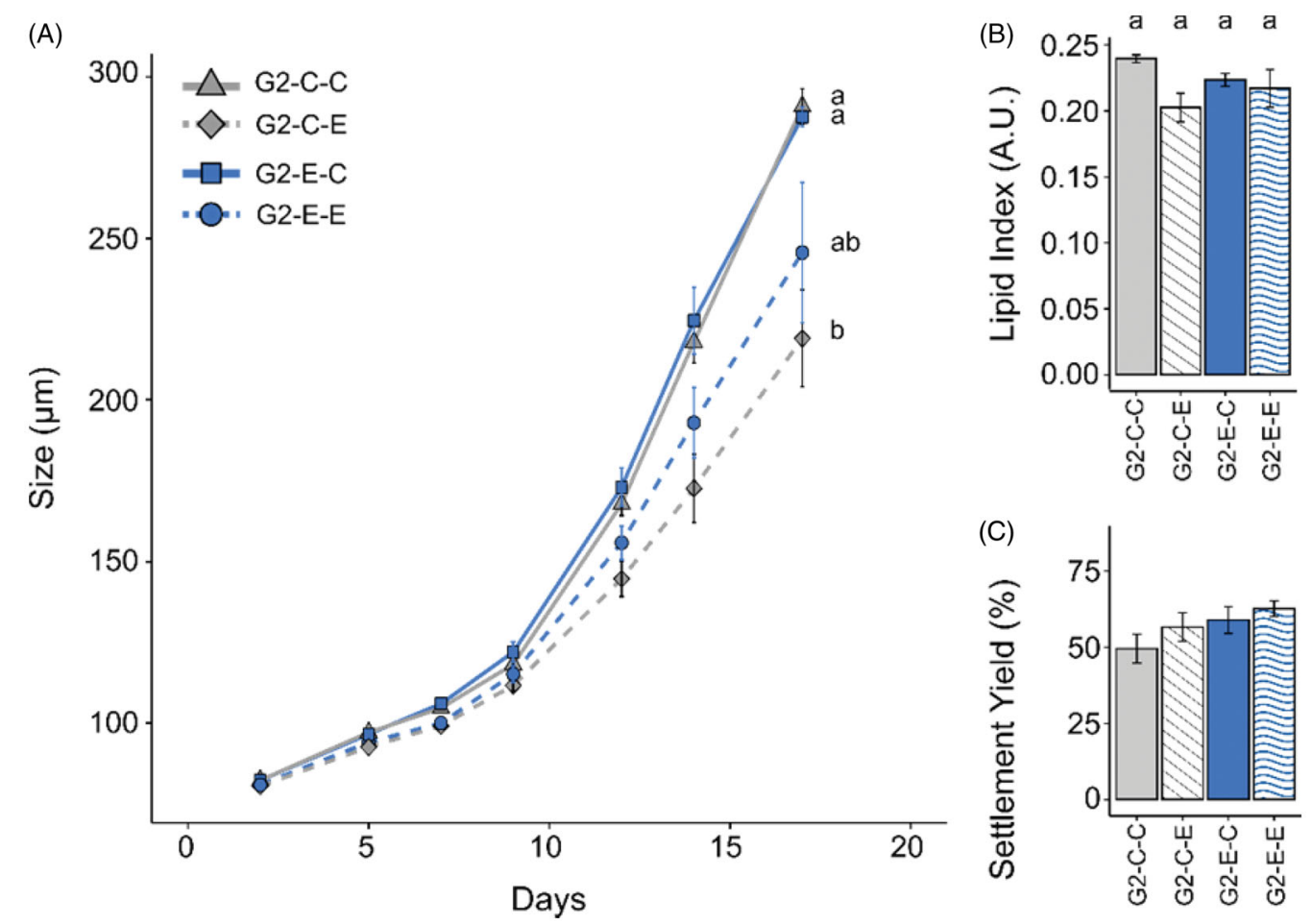

Figure 6. Size ( $\mu \mathrm{m}$; A), lipid index (A.U.; B) and settlement yield (\%; C) of G2 larvae issued from (i) G1 and G2 control embryos (G2-C-C; grey), (ii) G1 control embryos and G2 embryos exposed to $50-\mathrm{NH}_{2}$ at $0.1 \mu \mathrm{g} \mathrm{mL} \mathrm{L}^{-1}$ (G2-C-E; dashed grey), (iii) G1 embryos exposed to $50-\mathrm{NH}_{2}$ at $0.1 \mu \mathrm{g} \mathrm{mL} \mathrm{m}^{-1}$ and $\mathrm{G} 2$ control embryos (G2-E-C; blue), (iv) G1 and G2 embryos exposed to $50-\mathrm{NH}_{2}$ at $0.1 \mu \mathrm{g}$ $\mathrm{mL}^{-1}$ (G2-E-E; dashed blue). Results are expressed as means $\pm \mathrm{SE}$ ( $n=4$ for size and lipid index; $n=2$ for the settlement yield). Repeated measures ANOVA were conducted to compare treatments for the size while one-way ANOVA was used for the lipid index at the $5 \%$ level; homogeneous groups are indicated by the same letter.

balance between embryogenic trajectories governed by molecular/cellular programming and the surrounding conditions with its external pressures, notably stressors, for which embryos can show developmental plasticity (Hamdoun and Epel 2007). Energy metabolism, for example, glucose and lipid metabolism, is crucial for embryo development (e.g. Jaeckle and Manahan 1989; Rafalski, Mancini, and 
Brunet 2012). Among lipids composition, cardiolipin $(\mathrm{CL})$ appeared modified, with a greater relative proportion in D-larvae issued from exposed embryos $(+9.7 \%) . \mathrm{CL}$ is a key and unique phospholipid located in the inner membrane of mitochondria, being the primary supplier of energy (ATP) used by organisms for basal maintenance, growth, development, and storage (Houtkooper and Vaz 2008; Sokolova et al. 2012). Specifically, CL has a major role in the functioning of oxidative phosphorylation, allowing the formation of ATP from ADP as it binds to oxidative phosphorylation complexes to ensure their stability and ATP production (Houtkooper and Vaz 2008; Paradies et al. 2014). Therefore, the observed increase in the relative $\mathrm{CL}$ content may suggest modification in the respiratory chain in oyster embryos exposed to $50-\mathrm{NH}_{2}$ beads. For instance, an increase in $\mathrm{CL}$ proportion can affect cell bioenergetics, associated with a decrease in the membrane electron flux and in ATP synthesis (Julienne et al. 2014; Shaikh et al. 2014). In parallel, recent findings demonstrated that nano-PS beads can reduce ATP production; for example, a decrease of $49-65 \%$ in ATP production by zebrafish embryos exposed to 50-nm PS-beads at $10 \mu \mathrm{g} \mathrm{mL}^{-1}$ (Trevisan et al. 2019). Such impairment may alter the overall embryo energy balance at the expense of key maintenance and developmental processes, leading to a slower larval growth as observed here. As ATP production was not measured here, further investigations including transcriptomic analyses and biochemical assays of mitochondrial functioning at each step of embryo development, coupled with bioenergetic modeling, would help to test this hypothesis.

Regarding the ability of nano-PS to impact cell membranes (Rossi, Barnoud, and Monticelli 2014; Feng et al. 2019; González-Fernández et al. 2020), lipid analyses showed no effect of $50-\mathrm{NH}_{2}$ at $0.1 \mu \mathrm{g}$ $\mathrm{mL}^{-1}$ on external membranes composition and integrity of oyster embryos. Nevertheless, we cannot exclude that higher concentrations could lead to membrane disruptions, as suggested by the drastic developmental arrests previously observed in oyster embryos exposed to higher doses (from $1 \mu \mathrm{g}$ $\mathrm{mL}^{-1}$ ) of nano-PS beads (Tallec et al. 2018). Such a loss of membrane integrity was, for example, highlighted in cyanobacteria exposed to $50-\mathrm{NH}_{2}$ beads at 2.5 and $4 \mu \mathrm{g} \mathrm{mL}^{-1}$ (Feng et al. 2019).
In agreement with high D-larval yield (>80\%), malformations or developmental arrests were not observed by optical microscopy, indicating there was no strong acute toxicity upon exposure to nano-PS at $0.1 \mu \mathrm{g} \mathrm{mL}^{-1}$ determined as sub-lethal. SEM observations revealed holes and asperities on the shells of D-larvae mostly issued from exposed embryos, however, the low number of larvae analyzed $(n=12)$ makes it impossible to draw any firm conclusion. In previous literature, disruption of calcium carbonate production and deposition was suspected in mussel embryos after $50-\mathrm{NH}_{2}$ exposure $\left(0.15 \mu \mathrm{g} \mathrm{mL}^{-1}\right)$ based on transcriptomic profiles (Balbi et al. 2017). Because the shell of bivalve larvae have an essential protective role (against physical damage, pathogens, predators, or pollutants (Arivalagan et al. 2017), investigations of shell biomineralization in marine bivalves in response to nanoplastics exposure combining both -omics approach and high throughput SEM observations would be of relevant interest.

\subsection{Repercussions of the embryonic exposure on oyster larval growth}

Typically, in C. gigas the time to reach the competent stage in the used rearing system at $25^{\circ} \mathrm{C}$ is around $16 \mathrm{dpf}$ as observed for the $\mathrm{G} 1$ and $\mathrm{G} 2$ larval rearing originated from unexposed embryos with the size of competent larvae aligned with those from the literature $(\sim 300 \mu \mathrm{m})$ (e.g. Rico-Villa et al. 2008).

Many studies have examined the effects of contaminants on early life stages (ELS), but the consequences of sub-lethal effects in ELS performances later in life remain mostly undetermined despite their crucial role in species sustainability. The decrease in larval growth and the delay in reaching the metamorphosis-competent stage observed in treatments exposed only once, i.e. G1-E and G2-C-E, may be viewed as consequences of effects that occurred on exposed embryos. The observed slowdown in larval growth could be associated with a lower accumulation of storage lipids during the pelagic phase, as remarked with $20 \%$ lower lipid index in the first generation larvae issued from exposed embryos; a similar trend was observed in the second generation, although the decrease was not significant. Indeed, bivalve larvae that 
accumulate fewer lipids can need more time to reach the metamorphosis-competent stage (Talmage and Gobler 2010) showing the crucial role that lipids play throughout larval development among entry, use, and accumulation of stored energy. Lipid storage reduction in response to embryonic exposure may originate from a perturbation in the establishment of larval digestive functions, already suggested by transcriptional profiles in mussel embryos exposed to $50-\mathrm{NH}_{2}$ beads (Balbi et al. 2017). Nevertheless, although the extension of time to reach metamorphosis can expose bivalve larvae to more in situ stress and mortality (Talmage and Gobler 2010), the one-day delay observed in the present study for larvae issued from embryonic exposure is low and cannot be extrapolated in situ considering the optimal rearing conditions used in our experimental facility. Metamorphosis and settlement success requires large amounts of the energy stored during larval development (Bochenek et al. 2001). Here, the settlement yield was similar among treatments, highlighting that suspected effects on the energy accumulated during larval development were not serious enough to impair the larval ability to metamorphose. Therefore, these results suggest negligible repercussions of the embryonic exposure to nano-PS on the oyster larvae. Nevertheless, it should also be considered that the favorable rearing conditions used here may have counteracted any adverse effect. Indeed, harsher environmental conditions during larval growth are expected to emphasize the sensitivity of animals to individual stressors and cocktail effects. To test the occurrence of adverse mid-term effects upon embryonic nanoPS exposure in more realistic conditions, it would be interesting in future works to consider other stressors occurring in the natural environment during the larval development (natural food variations/ limitations, pathogens, contaminants) in addition to plastic exposures.

\subsection{Embryonic exposure did not induce phenotype differences at the adult stage}

By monitoring the growth, ecophysiology, and gametogenesis of the $\mathrm{G} 1$ adult oysters over several months, we investigated potential 'maladaptive tuning,' i.e. the emergence of new phenotypes at the adult stage in response to embryonic exposure leading to reduced fitness (Hamdoun and Epel 2007). For instance, zebrafish exposed to PAH during embryonic development had reduced cardiovascular performances at the adult stage (Hicken et al. 2011). Here, adult oysters displayed similar growth, ecophysiological characteristics, and reproductive outputs (gametes and larval quality) whether they had grown from exposed embryos or controls. Therefore, these results imply that the suggested alterations observed at the embryonic and larval stages (cardiolipins relative content, larval growth) upon embryonic exposure to nano-PS at $0.1 \mu \mathrm{g}$ $\mathrm{mL}^{-1}$ were compensated as they did not induce any delayed effect in the ecophysiological, growth, and reproductive performances of adult oysters in our experimental conditions.

\subsection{Are there any memory-stress mechanisms occurring upon nano-PS exposure?}

To understand the risk of contaminants to population stability and estimate population resilience, it is important to determine how the sensitivity of animals can evolve across generations. Early life stages correspond to an especially sensitive window during which any subtle changes may be transferred across generations owing to the differentiation of primordial germ cells during early development phases. Thus, the environment during early life can induce an inter-generational effect in the progeny of the next generation (Burton and Metcalfe 2014). This could occur through epigenetic inheritance, i.e. modification of gene expression by adding chemical marks (e.g. DNA methylation), that could modify positively or negatively responses to the contaminants over subsequent generations (Vandegehuchte and Janssen 2014). Although epigenetics research on marine invertebrates is in its infancy, early findings have indicated that DNA methylations are of great importance in the embryonic development success of $C$. gigas. Inhibition of DNA methyltransferase (DNMT) was demonstrated to impact oyster embryo-larval development success (Rivière et al. 2013). Moreover, it was recently suggested that modifications of DNA methylation levels of specific homeobox genes can be one of the origins of copper embryotoxicity in oyster (Sussarellu et al. 2018) probably through the negative relationship of transcription level and specific DNA methylation of 
these homeobox genes (Rivière et al. 2013). In the present study, results did not suggest evidence of epigenetic changes or occurrence of a stress-memory mechanism as intergenerational effects were not recorded on the phenotype of G2-larvae issued from embryonic exposure at $\mathrm{G} 1$ or both generations. Nevertheless, the first evidence of epigenetic changes in oyster embryos faced stressors (i.e. copper, Sussarellu et al. 2018) and our observation of intermediate but non-significant growth rate of oyster larvae originated from embryos exposed at both generations call for more research to explore adaptive mechanisms during repeated exposures to pollutants such as plastics.

\section{Conclusion}

Understanding the risks of plastic debris for marine ecosystems implied the assessment of direct effects and potential repercussions after pulsed or chronic exposures. The present study aimed to assess the repercussions of embryonic exposure, a sensitive stage that could affect subsequent stages (larvae, juveniles, adults) and generations. Overall, the results suggested that short-term embryonic exposures to amino-nanopolystyrene at $0.1 \mu \mathrm{g} \mathrm{mL}$ cause low effects on oyster larvae with a slight but significant growth reduction with no consequences on the settlement yield nor on the adult stage in terms of growth, reproduction, and ecophysiological performances. No intergenerational effects were revealed on larvae, the stage we monitored in the second generation. These experimental approaches used under aquaculture procedures cannot be extrapolated to environmental situations where biological and anthropogenic compounds complexities occur but provide essential data on mechanistic understanding of plastic particles toxicity.

\section{Acknowledgments}

The authors thank the staff of the Ifremer experimental station at Argenton and nursery at Bouin for their help. We thank the PIMM Platform (UBO) for the help in electron microscopy. The authors also thank H. McCombie for her help in editing the English.

\section{Disclosure statement}

The authors report no conflict of interest. K. Tallec has a French doctoral grant from the Region Bretagne (50\%) and Ifremer (50\%).

\section{Funding}

This study was supported by the Agence Nationale de la Recherche (ANR) - Nanoplastics project (ANR-15-CE34-0006).

\section{ORCID}

K. Tallec (iD http://orcid.org/0000-0002-9813-6015

I. Paul-Pont (iD http://orcid.org/0000-0003-3734-0909

M. Boulais (D) http://orcid.org/0000-0002-9309-9278

C. Lambert (iD http://orcid.org/0000-0002-5885-467X

P. Soudant (iD http://orcid.org/0000-0003-3090-5612

A. Huvet (ID http://orcid.org/0000-0001-6912-881X

\section{References}

Alliegro, M. C., and D. A. Wright. 1983. "Polyspermy Inhibition in the Oyster, Crassostrea virginica." The Journal of Experimental Zoology 227 (1): 127-137. doi:10.1002/jez. 1402270117.

Al-Sid-Cheikh, M., S. J. Rowland, K. Stevenson, C. Rouleau, T. B. Henry, and R. C. Thompson. 2018. “Uptake, WholeBody Distribution, and Depuration of Nanoplastics by the Scallop Pecten maximus at Environmentally Realistic Concentrations." Environmental Science \& Technology 52 (24): 14480-14486. doi:10.1021/acs.est.8b05266.

Arivalagan, J., T. Yarra, B. Marie, V. A. Sleight, E. DuvernoisBerthet, M. S. Clark, A. Marie, and S. Berland. 2017. "Insights from the Shell Proteome: Biomineralization to Adaptation." Molecular Biology and Evolution 34 (1): 66-77. doi:10.1093/molbev/msw219.

Auguste, M., T. Balbi, C. Ciacci, B. Canonico, S. Papa, A. Borello, L. Vezzulli, and L. Canesi. 2020. "Shift in Immune Parameters after Repeated Exposure to Nanoplastics in the Marine Bivalve Mytilus." Frontiers in Immunology 11: 426. doi:10.3389/fimmu.2020.00426.

Balbi, T., G. Camisassi, M. Montagna, R. Fabbri, S. Franzellitti, C. Carbone, K. Dawson, and L. Canesi. 2017. "Impact of Cationic Polystyrene Nanoparticles $\left(\mathrm{PS}-\mathrm{NH}_{2}\right)$ on Early Embryo Development of Mytilus galloprovincialis: Effects on Shell Formation." Chemosphere 186: 1-9. doi:10.1016/j. chemosphere.2017.07.120.

Bayne, B. 2017. Biology of Oysters. Waltham, MA: Academic Press.

Bayne, B. L., A. J. S. Hawkins, and E. Navarro. 1987. "Feeding and Digestion by the Mussel Mytilus edulis L. (Bivalvia: Mollusca) in Mixtures of Silt and Algal Cells at Low Concentrations." Journal of Experimental Marine Biology 
and Ecology 111 (1): 1-22. doi:10.1016/0022-0981(87) 90017-7.

Beiras, R., J. Bellas, J. Cachot, B. Cormier, X. Cousin, M. Engwall, C. Gambardella, et al. 2018. "Ingestion and Contact with Polyethylene Microplastics Does Not Cause Acute Toxicity on Marine Zooplankton." Journal of Hazardous Materials 360: 452-460. doi:10.1016/j.jhazmat. 2018.07.101.

Besseling, E., B. Wang, M. Lürling, and A. A. Koelmans. 2014. "Nanoplastic Affects Growth of $S$. obliquus and Reproduction of D. magna." Environmental Science \& Technology 48 (20): 12336-12343. doi:10.1021/es503001d.

Bhandari, R. K., F. S. Vom Saal, and D. E. Tillitt. 2015. "Transgenerational Effects from Early Developmental Exposures to Bisphenol a or 17a-Ethinylestradiol in Medaka, Oryzias latipes." Scientific Reports 5 (1): 9303. doi: 10.1038/srep09303.

Bochenek, E., J. Klinck, E. Powell, and E. Hofmann. 2001. "A Biochemically Based Model of the Growth and Development of Crassostrea gigas Larvae." Journal of Shellfish Research 20 (1): 243-265.

Boulais, M., P. Soudant, N. Le Goïc, C. Quéré, P. Boudry, and M. Suquet. 2015. "Involvement of Mitochondrial Activity and OXPHOS in ATP Synthesis during the Motility Phase of Spermatozoa in the Pacific Oyster, Crassostrea gigas." Biology of Reproduction 93 (5): 1-7. doi:10.1095/biolreprod. 115.128538.

Burton, T., and N. B. Metcalfe. 2014. "Can Environmental Conditions Experienced in Early Life Influence Future Generations?" Proceedings. Biological Sciences 281 (1785): 20140311. doi:10.1098/rspb.2014.0311.

Chen, Q., M. Gundlach, S. Yang, J. Jiang, M. Velki, D. Yin, and H. Hollert. 2017. "Quantitative Investigation of the Mechanisms of Microplastics and Nanoplastics Toward Zebrafish Larvae Locomotor Activity." Science of the Total Environment 584-585: 1022-1031. doi:10.1016/j.scitotenv. 2017.01.156.

Cole, M., P. Lindeque, C. Halsband, and T. S. Galloway. 2011. "Microplastics as Contaminants in the Marine Environment: A review." Marine Pollution Bulletin 62 (12): 2588-2597. doi:10.1016/j.marpolbul.2011.09.025.

Conover, R. J. 1966. "Assimilation of Organic Matter by Zooplankton." Limnology and Oceanography 11 (3): 338-345. doi:10.4319/lo.1966.11.3.0338.

Da Costa, F., B. Petton, C. Mingant, G. Bougaran, C. Rouxel, C. Quéré, G. H. Wikfors, P. Soudant, and R. Robert. 2016. "Influence of One Selected Tisochrysis lutea Strain Rich in Lipids on Crassostrea gigas Larval Development and Biochemical Composition." Aquaculture Nutrition 22 (4): 813-836. doi:10.1111/anu.12301.

Dawson, A. L., S. Kawaguchi, C. K. King, K. A. Townsend, R. King, W. M. Huston, and S. M. Bengtson Nash. 2018. "Turning Microplastics into Nanoplastics through Digestive Fragmentation by Antarctic Krill." Nature Communications 9 (1): 1001. doi:10.1038/s41467-018-03465-9.

Della Torre, C., E. Bergami, A. Salvati, C. Faleri, P. Cirino, K. A. Dawson, and I. Corsi. 2014. "Accumulation and
Embryotoxicity of Polystyrene Nanoparticles at Early Stage of Development of Sea Urchin Embryos Paracentrotus lividus." Environmental Science \& Technology 48 (20): 12302-12311. doi:10.1021/es502569w.

Ekvall, M. T., M. Lundqvist, E. Kelpsiene, E. Šileikis, S. B. Gunnarsson, and T. Cedervall. 2019. "Nanoplastics Formed during the Mechanical Breakdown of Daily-Use Polystyrene Products." Nanoscale Advances 1 (3): 1055-1061. doi:10.1039/C8NA00210J.

Eriksen, M., L. C. M. Lebreton, H. S. Carson, M. Thiel, C. J. Moore, J. C. Borerro, F. Galgani, P. G. Ryan, and J. Reisser. 2014. "Plastic Pollution in the World's Oceans: More than 5 Trillion Plastic Pieces Weighing over 250,000 Tons Afloat at Sea." PLoS One 9 (12): e111913. doi:10.1371/journal. pone.0111913.

Fabioux, C., A. Huvet, P. Le Souchu, M. Le Pennec, and S. Pouvreau. 2005. "Temperature and Photoperiod Drive Crassostrea gigas Reproductive Internal Clock." Aquaculture 250 (1-2): 458-470. doi:10.1016/j.aquaculture.2005.02.038.

Feng, L., J.-W. Li, E. G. Xu, X.-D. Sun, F.-P. Zhu, Z.-J. Ding, H.Y. Tian, S.-S. Dong, P.-F. Xia, and X.-Z. Yuan. 2019. "ShortTerm Exposure to Positively Charged Polystyrene Nanoparticles Causes Oxidative Stress and Membrane Destruction in Cyanobacteria." Environmental Science: Nano 6 (10): 3072-3079. doi:10.1039/C9EN00807A.

Fitzpatrick, J. L., S. Nadella, C. Bucking, S. Balshine, and C. M. Wood. 2008. "The Relative Sensitivity of Sperm, Eggs and Embryos to Copper in the Blue Mussel (Mytilus trossulus)." Comparative Biochemistry and Physiology. Toxicology \& Pharmacology 147 (4): 441-449. doi:10.1016/j.cbpc.2008. 01.012.

Foulon, V., F. Le Roux, C. Lambert, A. Huvet, P. Soudant, and I. Paul-Pont. 2016. "Colonization of Polystyrene Microparticles by Vibrio crassostreae: Light and Electron Microscopic Investigation." Environmental Science \& Technology 50 (20): 10988-10996.

Galloway, T. S., M. Cole, and C. Lewis. 2017. "Interactions of Microplastic Debris throughout the Marine Ecosystem." Nature Ecology \& Evolution 1 (5): 116. doi:10.1038/s41559017-0116.

Geyer, R., J. R. Jambeck, and K. L. Law. 2017. "Production, Use, and Fate of All Plastics Ever Made." Science Advances 3 (7): e1700782. doi:10.1126/sciadv.1700782.

Gigault, J., B. Pedrono, B. Maxit, and A. Ter Halle. 2016. "Marine Plastic Litter: The Unanalyzed Nano-Fraction." Environmental Science: Nano 3 (2): 346-350. doi:10.1039/ C6EN00008H.

González-Fernández, C., F. Le Grand, A. Bideau, A. Huvet, I. Paul-Pont, and P. Soudant. 2020. "Nanoplastics Exposure Modulate Lipid and Pigment Compositions in Diatoms." Environmental Pollution 262: 114274. doi:10.1016/j.envpol. 2020.114274.

Halpern, B. S., S. Walbridge, K. A. Selkoe, C. V. Kappel, F. Micheli, C. D'Agrosa, J. F. Bruno, et al. 2008. "A Global Map of Human Impact on Marine Ecosystems." Science 319 (5865): 948-952. doi:10.1126/science.1149345. 
Hamdoun, A., and D. Epel. 2007. "Embryo Stability and Vulnerability in an Always Changing World." Proceedings of the National Academy of Sciences of the United States of America 104 (6): 1745-1750. doi:10.1073/pnas.0610108104. Hernandez, L. M., N. Yousefi, and N. Tufenkji. 2017. "Are There Nanoplastics in Your Personal Care Products?" Environmental Science \& Technology Letters 4 (7): 280-285. doi:10.1021/acs.estlett.7b00187.

Hicken, C. E., T. L. Linbo, D. H. Baldwin, M. L. Willis, M. S. Myers, L. Holland, M. Larsen, et al. 2011. "Sublethal Exposure to Crude Oil during Embryonic Development Alters Cardiac Morphology and Reduces Aerobic Capacity in Adult Fish." Proceedings of the National Academy of Sciences of the United States of America 108 (17): 7086-7090. doi:10.1073/pnas.1019031108.

Houtkooper, R. H., and F. M. Vaz. 2008. "Cardiolipin, the Heart of Mitochondrial Metabolism." Cellular and Molecular Life Sciences 65 (16): 2493-2506. doi:10.1007/ s00018-008-8030-5.

Jaeckle, W. B., and D. T. Manahan. 1989. "Growth and Energy Imbalance during the Development of a Lecithotrophic Molluscan Larva (Haliotis Rufescens)." The Biological Bulletin 177 (2): 237-246. doi:10.2307/1541939.

Jeong, C. B., E. J. Won, H. M. Kang, M. C. Lee, D. S. Hwang, U. K. Hwang, B. Zhou, S. Souissi, S. J. Lee, and J. S. Lee. 2016. "Microplastic Size-Dependent Toxicity, Oxidative Stress Induction, and p-JNK and p-p38 Activation in the Monogonont Rotifer (Brachionus Koreanus)." Environmental Science \& Technology 50 (16): 8849-8857. doi:10.1021/acs. est.6b01441.

Julienne, C. M., M. Tardieu, S. Chevalier, M. Pinault, P. Bougnoux, F. Labarthe, C. Couet, S. Servais, and J.-F. Dumas. 2014. "Cardiolipin Content is Involved in Liver Mitochondrial Energy Wasting Associated with CancerInduced Cachexia without the Involvement of Adenine Nucleotide Translocase." Biochimica et Biophysica Acta 1842 (5): 726-733. doi:10.1016/j.bbadis.2014.02.003.

Lambert, S., and M. Wagner. 2016. "Formation of Microscopic Particles during the Degradation of Different Polymers." Chemosphere 161: 510-517. doi:10.1016/j.chemosphere. 2016.07.042.

Le Grand, F., P. Soudant, A. Siah, R. Tremblay, Y. Marty, and E. Kraffe. 2014. "Disseminated Neoplasia in the Soft-Shell Clam Mya arenaria: Membrane Lipid Composition and Functional Parameters of Circulating Cells." Lipids 49 (8): 807-818. doi:10.1007/s11745-014-3917-4.

Leclère, L., M. Jager, C. Barreau, P. Chang, H. Le Guyader, M. Manuel, and E. Houliston. 2012. "Maternally Localized Germ Plasm mRNAs and Germ Cell/Stem Cell Formation in the Cnidarian Clytia." Developmental Biology 364 (2): 236-248. doi:10.1016/j.ydbio.2012.01.018.

Lehner, R., C. Weder, A. Petri-Fink, and B. RothenRutishauser. 2019. "Emergence of Nanoplastic in the Environment and Possible Impact on Human Health." Environmental Science \& Technology 53 (4): 1748-1765. doi:10.1021/acs.est.8b05512.
Liu, Z., M. Cai, D. Wu, P. Yu, Y. Jiao, Q. Jiang, and Y. Zhao. 2020. "Effects of Nanoplastics at Predicted Environmental Concentration on Daphnia pulex after Exposure through Multiple Generations." Environmental Pollution 256: 113506. doi:10.1016/j.envpol.2019.113506.

Luis Stephano, J., and M. Gould. 1988. "Avoiding Polyspermy in Oyster (Crassostrea Gigas)." Aquaculture 73 (1-4): 295-307. doi:10.1016/0044-8486(88)90063-4.

Major, K. M., B. M. DeCourten, J. Li, M. Britton, M. L. Settles, A. C. Mehinto, R. E. Connon, and S. M. Brander. 2020. “Early Life Exposure to Environmentally Relevant Levels of Endocrine Disruptors Drive Multigenerational and Transgenerational Epigenetic Changes in a Fish Model." Frontiers in Marine Science 7: 471 doi:10.3389/fmars.2020. 00471.

Manfra, L., A. Rotini, E. Bergami, G. Grassi, C. Faleri, and I. Corsi. 2017. "Comparative Ecotoxicity of Polystyrene Nanoparticles in Natural Seawater and Reconstituted Seawater Using the Rotifer Brachionus plicatilis." Ecotoxicology and Environmental Safety 145: 557-563. doi: 10.1016/j.ecoenv.2017.07.068.

Mateos-Cárdenas, A., J. O'Halloran, F. N. A. M. van Pelt, and M. A. K. Jansen. 2020. "Rapid Fragmentation of Microplastics by the Freshwater Amphipod Gammarus duebeni (Lillj.)." Scientific Reports 10 (1): 12799. doi:10. 1038/s41598-020-69635-2.

Mintenig, S. M., P. S. Bäuerlein, A. A. Koelmans, S. C. Dekker, and A. P. Van Wezel. 2018. "Closing the Gap between Small and Smaller: Towards a Framework to Analyse Nano- and Microplastics in Aqueous Environmental Samples." Environmental Science 5 (7): 1640-1649.

Mottier, A., V. Kientz-Bouchart, A. Serpentini, J. M. Lebel, A. N. Jha, and K. Costil. 2013. "Effects of glyphosate-based herbicides on embryo-larval development and metamorphosis in the Pacific oyster, Crassostrea gigas." Aquatic Toxicology 128-129: 67-78. doi:10.1016/j.aquatox.2012.12. 002.

Moutel, B., O. Gonçalves, F. Le Grand, M. Long, P. Soudant, J. Legrand, D. Grizeau, and J. Pruvost. 2016. "Development of a Screening Procedure for the Characterization of Botryococcus braunii Strains for Biofuel Application." Process Biochemistry 51 (11): 1855-1865. doi:10.1016/j. procbio.2016.05.002.

Paradies, G., V. Paradies, V. De Benedictis, F. M. Ruggiero, and G. Petrosillo. 2014. "Functional Role of Cardiolipin in Mitochondrial Bioenergetics." Biochimica et Biophysica Acta 1837 (4): 408-417. doi:10.1016/j.bbabio.2013.10.006.

Paul-Pont, I., K. Tallec, C. Gonzalez-Fernandez, C. Lambert, D. Vincent, D. Mazurais, J.-L. Zambonino-Infante, et al. 2018. "Constraints and Priorities for Conducting Experimental Exposures of Marine Organisms to Microplastics." Frontiers in Marine Science 5: 1-22. doi:10.3389/fmars.2018.00252.

Pechenik, J. 1999. "On the Advantages and Disadvantages of Larval Stages in Benthic Marine Invertebrate Life Cycles." Marine Ecology Progress Series 177: 269-297. doi:10.3354/ meps177269. 
Petton, B., F. Pernet, R. Robert, and P. Boudry. 2013. "Temperature Influence on Pathogen Transmission and Subsequent Mortalities in Juvenile Pacific Oysters Crassostrea gigas." Aquaculture Environment Interactions 3 (3): 257-273. doi:10.3354/aei00070.

Pousse, É., J. Flye-Sainte-Marie, M. Alunno-Bruscia, H. Hégaret, and F. Jean. 2018. "Sources of Paralytic Shellfish Toxin Accumulation Variability in the Pacific Oyster Crassostrea gigas." Toxicon 144: 14-22. doi:10.1016/j.toxicon.2017.12.050.

R Core Team. 2016. R: A Language and Environment for Statistical Computing. Vienna, Austria: R Foundation for Statistical Computing.

Rafalski, V. A., E. Mancini, and A. Brunet. 2012. “Energy Metabolism and Energy-Sensing Pathways in Mammalian Embryonic and Adult Stem Cell Fate." Journal of Cell Science 125 (23): 5597-5608. doi:10.1242/jcs.114827.

Rico-Villa, B., P. Woerther, C. Mingant, D. Lepiver, S. Pouvreau, M. Hamon, and R. Robert. 2008. "A Flowthrough Rearing System for Ecophysiological Studies of Pacific Oyster Crassostrea gigas Larvae." Aquaculture 282 (1-4): 54-60. doi:10.1016/j.aquaculture.2008.06.016.

Rivière, G., G. Wu, A. Fellous, D. Goux, P. Sourdaine, and P. Favrel. 2013. "DNA Methylation is Crucial for the Early Development in the Oyster C. gigas." Marine Biotechnology 15 (6): 739-753. doi:10.1007/s10126-013-9523-2.

Robert, R., and A. Gérard. 1999. "Bivalve Hatchery Technology: The Current Situation for the Pacific Oyster Crassostrea gigas and the Scallop Pecten maximus in France." Aquatic Living Resources 12 (2): 121-130. doi:10. 1016/S0990-7440(99)80021-7.

Rossi, G., J. Barnoud, and L. Monticelli. 2014. "Polystyrene Nanoparticles Perturb Lipid Membranes." The Journal of Physical Chemistry Letters 5 (1): 241-246. doi:10.1021/ jz402234c.

Savina, M., and S. Pouvreau. 2004. "A Comparative Ecophysiological Study of Two Infaunal Filter-Feeding Bivalves: Paphia rhomboïdes and Glycymeris glycymeris." Aquaculture 239 (1-4): 289-306. doi:10.1016/j.aquaculture. 2004.05.029.

Shaikh, S. R., E. M. Sullivan, R. J. Alleman, D. A. Brown, and T. N. Zeczycki. 2014. "Increasing Mitochondrial Membrane Phospholipid Content Lowers the Enzymatic Activity of Electron Transport Complexes." Biochemistry 53 (35): 5589-5591. doi:10.1021/bi500868g.

Sokolova, I. M., M. Frederich, R. Bagwe, G. Lannig, and A. A. Sukhotin. 2012. "Energy Homeostasis as an Integrative Tool for Assessing Limits of Environmental Stress Tolerance in Aquatic Invertebrates." Marine Environmental Research 79: 1-15. doi:10.1016/j.marenvres.2012.04.003.

Steele, S., and M. F. Mulcahy. 1999. "Gametogenesis of the Oyster Crassostrea gigas in Southern Ireland." Journal of the Marine Biological Association of the United Kingdom 79 (4): 673-686. doi:10.1017/S0025315498000836.
Stephens, B., P. Azimi, Z. El Orch, and T. Ramos. 2013. "Ultrafine Particle Emissions from Desktop 3D Printers." Atmospheric Environment 79: 334-339. doi:10.1016/j.atmosenv.2013.06.050.

Sussarellu, R., M. Lebreton, J. Rouxel, F. Akcha, and G. Rivière. 2018. "Copper Induces Expression and Methylation Changes of Early Development Genes in Crassostrea gigas Embryos." Aquatic Toxicology 196: 70-78. doi:10.1016/j.aquatox.2018.01.001.

Sussarellu, R., M. Suquet, Y. Thomas, C. Lambert, C. Fabioux, M. E. J. Pernet, N. Le Goïc, et al. 2016. "Oyster Reproduction is Affected by Exposure to Polystyrene Microplastics." Proceedings of the National Academy of Sciences 113 (9): 2430-2435. doi:10.1073/pnas.1519019113.

Tallec, K., A. Huvet, C. Di Poi, C. González-Fernández, C. Lambert, B. Petton, N. Le Goïc, M. Berchel, P. Soudant, and I. Paul-Pont. 2018. "Nanoplastics Impaired Oyster Free Living Stages, Gametes and Embryos." Environmental Pollution 242 (B): 1226-1235. doi:10.1016/j.envpol.2018.08. 020.

Tallec, K., I. Paul-Pont, M. Boulais, N. Le Goïc, C. GonzálezFernández, F. Le Grand, A. Bideau, et al. 2020. “ Nanopolystyrene Beads Affect Motility and Reproductive Success of Oyster Spermatozoa (Crassostrea Gigas)." Nanotoxicology 14 (8): 1039-1057. doi:10.1080/17435390. 2020.1808104.

Talmage, S. C., and C. J. Gobler. 2010. "Effects of past, Present, and Future Ocean Carbon Dioxide Concentrations on the Growth and Survival of Larval Shellfish." Proceedings of the National Academy of Sciences of the United States of America 107 (40): 17246-17251. doi:10. 1073/pnas.0913804107.

Ter Halle, A., L. Jeanneau, M. Martignac, E. Jardé, B. Pedrono, L. Brach, and J. Gigault. 2017. "Nanoplastic in the North Atlantic Subtropical Gyre." Environmental Science \& Technology 51 (23): 13689-13697. doi:10.1021/acs.est. $7 \mathrm{~b} 03667$.

Trevisan, R., C. Voy, S. Chen, and R. T. Di Giulio. 2019. "Nanoplastics Decrease the Toxicity of a Complex PAH Mixture but Impair Mitochondrial Energy Production in Developing Zebrafish." Environmental Science \& Technology 53 (14): 8405-8415. doi:10.1021/acs.est. 9b02003.

van Sebille, E., C. Wilcox, L. Lebreton, N. Maximenko, B. D. Hardesty, J. A. van Franeker, M. Eriksen, D. Siegel, F. Galgani, and K. L. Law. 2015. "A Global Inventory of Small Floating Plastic Debris." Environmental Research Letters 10 (12): 124006. doi:10.1088/1748-9326/10/12/124006.

Vandegehuchte, M. B., and C. R. Janssen. 2014. "Epigenetics in an Ecotoxicological Context." Mutation Research Genetic Toxicology and Environmental Mutagenesis 764-765: 36-45. doi:10.1016/j.mrgentox.2013.08.008.

Vogeler, S., T. P. Bean, B. P. Lyons, and T. S. Galloway. 2016. "Dynamics of Nuclear Receptor Gene Expression during 
Pacific Oyster Development." BMC Developmental Biology 16 (1): 1-13. doi:10.1186/s12861-016-0129-6.

Wagner, S., and T. Reemtsma. 2019. "Things we Know and Don't Know About Nanoplastic in the Environment." Nature Nanotechnology 14 (4): 300-301. doi:10.1038/ s41565-019-0424-Z.

Zhang, H., Y. Y. Kuo, A. C. Gerecke, and J. Wang. 2012. "CoRelease of Hexabromocyclododecane (HBCD) and Nanoand Microparticles from Thermal Cutting of Polystyrene Foams." Environmental Science \& Technology 46 (20): 10990-10996. doi:10.1021/es302559v.
Zhang, Y., and G. G. Goss. 2020. "Potentiation of Polycyclic Aromatic Hydrocarbon Uptake in Zebrafish Embryos by Nanoplastics." Environmental Science: Nano 7 (6): 1730-1741. doi:10.1039/D0EN00163E.

Zhao, L., M. Qu, G. Wong, and D. Wang. 2017. "Transgenerational Toxicity of Nanopolystyrene Particles in the Range of $\mu \mathrm{g} \mathrm{L}^{-1}$ in the Nematode Caenorhabditis elegans." Environmental Science: Nano 4 (12): 2356-2366. doi: 10.1039/C7EN00707H. 